\title{
Histamine, Neuroinflammation and Neurodevelopment: A Review
}

\author{
Elliott Carthy ${ }^{1}$ and Tommas Ellender ${ }^{1,2 *}$ \\ ${ }^{1}$ Department of Pharmacology, University of Oxford, Oxford, United Kingdom, ${ }^{2}$ Department of Biomedical Sciences, \\ University of Antwerp, Antwerp, Belgium
}

\section{OPEN ACCESS}

Edited by:

Anayansi Molina-Hernández, Instituto Nacional de Perinatología

(INPER), Mexico

Reviewed by:

Fotis Tsetsos,

Democritus University of Thrace,

Greece

Ling Shan,

Netherlands Institute for Neuroscience

(KNAW), Netherlands

*Correspondence:

Tommas Ellender

tommas.ellender@pharm.ox.ac.uk; tommas.ellender@uantwerpen.be

Specialty section:

This article was submitted to

Neurodevelopment,

a section of the journal

Frontiers in Neuroscience

Received: 13 March 2021

Accepted: 18 June 2021

Published: 14 July 2021

Citation:

Carthy E and Ellender T (2021)

Histamine, Neuroinflammation

and Neurodevelopment: A Review.

Front. Neurosci. 15:680214.

doi: 10.3389/fnins.2021.680214
The biogenic amine, histamine, has been shown to critically modulate inflammatory processes as well as the properties of neurons and synapses in the brain, and is also implicated in the emergence of neurodevelopmental disorders. Indeed, a reduction in the synthesis of this neuromodulator has been associated with the disorders Tourette's syndrome and obsessive-compulsive disorder, with evidence that this may be through the disruption of the corticostriatal circuitry during development. Furthermore, neuroinflammation has been associated with alterations in brain development, e.g., impacting synaptic plasticity and synaptogenesis, and there are suggestions that histamine deficiency may leave the developing brain more vulnerable to proinflammatory insults. While most studies have focused on neuronal sources of histamine it remains unclear to what extent other (non-neuronal) sources of histamine, e.g., from mast cells and other sources, can impact brain development. The few studies that have started exploring this in vitro, and more limited in vivo, would indicate that nonneuronal released histamine and other preformed mediators can influence microglialmediated neuroinflammation which can impact brain development. In this Review we will summarize the state of the field with regard to non-neuronal sources of histamine and its impact on both neuroinflammation and brain development in key neural circuits that underpin neurodevelopmental disorders. We will also discuss whether histamine receptor modulators have been efficacious in the treatment of neurodevelopmental disorders in both preclinical and clinical studies. This could represent an important area of future research as early modulation of histamine from neuronal as well as non-neuronal sources may provide novel therapeutic targets in these disorders.

Keywords: histamine, brain, mast cells, microglia, neurodevelopment, neuroinflammation, astrocytes, neurodevelopmental disorders

\section{INTRODUCTION}

Histamine is a biogenic monoamine as well as an endogenous neurotransmitter with a diverse array of physiological functions, ranging from local inflammatory responses to regulating synaptic transmission in the brain. A select number of mammalian cell types synthesize histamine, including those of the immune system (Schwartz, 1987; Dvorak, 1997), such as mast cells (and basophils, platelets), as well as small populations of neurons in the brain (Haas and Panula, 2003), such a those found in the tuberomammillary nucleus (TMN) of the hypothalamus. In the human adult brain, there are approximately 64,000 histaminergic neurons located in and around the TMN (Haas et al., 2008). These project diffusely throughout all areas of the brain, differentially modulating many 
distinct neuronal circuits (Blandina et al., 2012). Once released histamine can have widespread effects throughout the brain at large numbers of different cell types that express one or more of the four known histamine $\mathrm{G}$ protein-coupled receptors (Panula et al., 2015).

A wealth of data has demonstrated clear roles for histamine acting directly on neurons and neuronal structures (Haas and Panula, 2003; Haas et al., 2008; Panula and Nuutinen, 2013; Shan et al., 2015; Bolam and Ellender, 2016; Yoshikawa et al., 2021), but much less is known how histamine can act on other cell types found in the brain. Indeed, the young developing brain exhibits high numbers of some of these other cell types (e.g., microglia and mast cells) whose numbers change dynamically during development. Moreover, the young developing brain also contains a permeable blood brain barrier resulting in the potential for access of systemic factors and immune cells to act on developing neurons and synapses. In this Review, we will focus on three different non-neuronal cell types found in the brain, the microglia, mast cells and astrocytes and their interaction with histamine. We will discuss how they are involved in histaminergic signaling in the brain and how aberrant behavior of these cell types can impact on the development of neurons and synapses (see Figure 1). This is of importance as histamine has been implicated in a variety of early onset neurodevelopmental disorders. Furthermore, we will also discuss whether histamine receptor modulators have been efficacious in the treatment of difficulties associated with neurodevelopmental disorders in both preclinical and clinical studies.

\section{HISTAMINE AND THE DEVELOPING BRAIN}

\section{Histamine Synthesis and Metabolism}

Histamine is synthesized from the amino acid, histidine. Histidine is one of the nine essential amino acids humans must get from their diet and is present in most proteinrich foods (e.g., fish, eggs, and nuts). Histidine undergoes oxidative decarboxylation by the enzyme histidine decarboxylase $(H d c)$, which is expressed by a select number of cells in the brain, including the histaminergic neurons in the TMN of the hypothalamus (Haas and Panula, 2003), transiently by other young developing neurons (Nissinen et al., 1995; Karlstedt et al., 2001a), but also by many non-neuronal cells including microglia and mast cells (Auvinen and Panula, 1988). Unlike for the other monoamines, no high-affinity histamine reuptake system has yet been identified in the mammalian brain [but see for Drosophila (Borycz et al., 2002; Chaturvedi et al., 2014; Stenesen et al., 2015; Xu et al., 2015)]. Although astrocytic plasma membrane monoamine and low-affinity organic cation transporters play a role in the uptake of histamine (Amphoux et al., 2006; Yoshikawa et al., 2013), this suggests that histamine is likely degraded in the extracellular space (Schwartz et al., 1991; Haas and Panula, 2003) with a possible half-life ranging in minutes (Schwartz et al., 1991). Inactivation of histamine within the central nervous system (CNS) occurs via methylation to inactive telemethylhistamine by the enzyme histamine $N$-methyltransferase
(HNMT) (Bowsher et al., 1983; Barnes and Hough, 2002; Haas et al., 2008) [see for recent review (Yoshikawa et al., 2021)]. Once released, histamine has multiple pleiotropic functions within the developing and mature central nervous system, including regulating neuronal excitability and neurotransmission (Haas et al., 2008), synaptic plasticity (Han et al., 2020), and immunomodulation (Forsythe, 2019) and has a functional role in modulating many aspects of behavior including learning, cognition, wakefulness, attention and memory (Haas and Panula, 2003; Haas et al., 2008; Passani et al., 2014). Given its effect at promoting wakefulness and attention, it will come as no surprise that histaminergic neuronal firing rates are highest during waking hours and low or silent during sleep (Takahashi et al., 2006; Lin et al., 2011) and that increases in histaminergic firing have been observed during periods of increased attention (Takahashi et al., 2006) and motivated behaviors (Torrealba et al., 2012).

\section{Sources of Histamine in the Developing Brain}

Histamine has been shown to be one of the earliest neuromodulators present within the developing embryonic rodent brain, with a prenatal peak seen around embryonic day (E)14 - 16 (Vanhala et al., 1994). Histamine-immunoreactive neurons can be found within various parts of the developing brain, including the rhombencephalon, mesencephalon, and in some regions of the diencephalon (Auvinen and Panula, 1988). These are a transient source of histamine, the peak of which coincides with periods of increased neurogenesis and the initial phase of gliogenesis, suggesting it may modulate these early processes (Sauvageot and Stiles, 2002; MolinaHernández and Velasco, 2008; Rodríguez-Martínez et al., 2012). In addition, transient sources of histamine in the brain include a subgroup of serotonergic neurons from the raphe nucleus that project widely in the brain and transiently co-express the synthesizing enzyme $H d c$ as well as histamine during early embryonic development (Wada et al., 1991; Vanhala et al., 1994; Molina-Hernández et al., 2012), and a population of thalamic neurons that also transiently expresses $H d c$ (Nissinen et al., 1995; Nissinen and Panula, 1995; Karlstedt et al., 2001a; Zecharia et al., 2012). The number of histamine-immunoreactive neurons in these regions then steadily decreases until E18, after which the histaminergic neurons of the TMN of the hypothalamus become detectable at E20 which project widely throughout the brain and form a main neuronal histaminergic source that persist into adulthood (Auvinen and Panula, 1988; Haas et al., 2008; Molina-Hernández et al., 2012). Neuronal histamine is stored within both the cell somata as well as within vesicles in axonal varicosities as packaged by the vesicular monoamine transporter (VMAT2) and is released by activated neurons (Haas et al., 2008; Puttonen et al., 2017). In addition, ependymal cells lining the ventricles also likely synthesize histamine as they express the synthesizing enzyme $H d c$ (Karlstedt et al., 2001a). Lastly, immune cells, including mast cells and microglia encompass non-neuronal sources of histamine (Katoh et al., 2001; Haas et al., 2008), which store histamine in granules, which are released when appropriately activated (Forsythe, 2019). 


\section{Neurodevelopment}

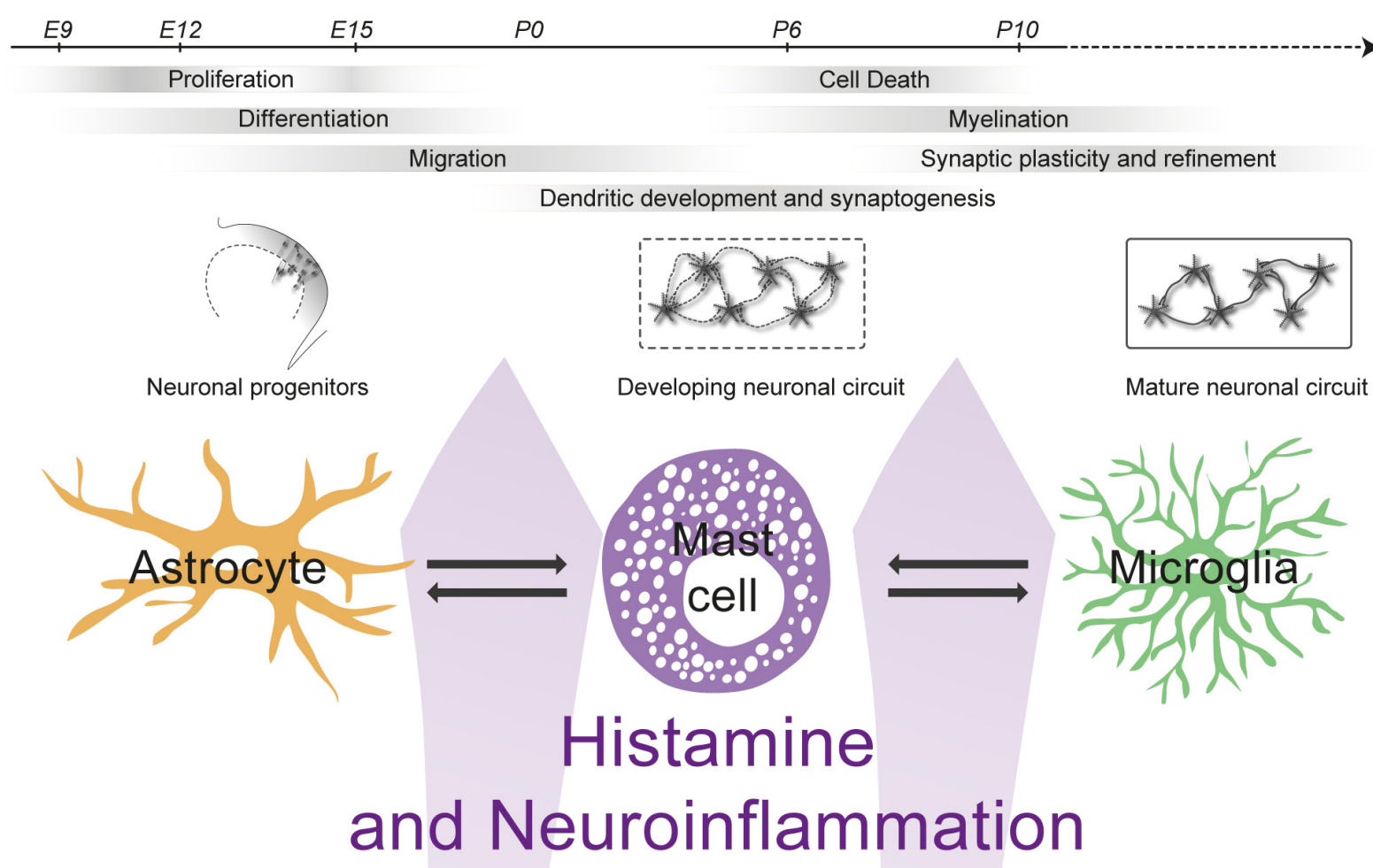

FIGURE 1 | The interactions between mast cells, astrocytes and microglia can impact levels of histamine and neuroinflammation influencing neurodevelopment.

We'll mainly focus on these other non-neuronal sources of histamine in this Review.

\section{Histamine Receptors}

Histamine acts at both neuronal and non-neuronal cells in the brain at one or more of the four known histamine $G$ proteincoupled receptors denoted as the $\mathrm{H}_{1}-\mathrm{H}_{4}$ receptors (Passani and Blandina, 2011; Panula et al., 2015; Haas and Panula, 2016). Three of the four histamine receptors $\left(\mathrm{H}_{1}, \mathrm{H}_{2}\right.$, and $\mathrm{H}_{3}$ receptors) are widely expressed throughout the CNS (Haas et al., 2008; MolinaHernández et al., 2012; Panula and Nuutinen, 2013; Haas and Panula, 2016). The $\mathrm{H}_{1}$ receptor is coupled to an intracellular $\mathrm{G}_{q}$ protein that activates phospholipase $\mathrm{C}$ and inositol triphosphate (IP3) signaling pathways. The $\mathrm{H}_{1}$ receptor has been identified in the developing rat CNS from E14 within the telencephalon, mesencephalon and the spinal cord (Kinnunen et al., 1998) and expression is retained into adulthood. The $\mathrm{H}_{2}$ receptors are coupled to $G_{s}$ second messenger proteins that increase the production of cyclic adenosine monophosphate (cAMP) and subsequent activation of protein kinase $A$. The $\mathrm{H}_{2}$ receptor is expressed early by neural stem cells at E12 and by neurons within the raphe nuclei, with subsequent uniform expression found throughout the rat brain by E15 (Molina-Hernández et al., 2012) with prominent expression in the cortical plate by E17 (Karlstedt et al., 2001b). The $\mathrm{H}_{3}$ receptors are coupled to $G_{i}$ second messenger proteins that have high constitutive activity and their expression is initially more restricted within the developing brain (Karlstedt et al., 2003; Molina-Hernández et al., 2012). At E15, they are predominantly expressed within the midbrain, medulla and spinal cord, with expression in the latter two diminishing after E16 and expression within the hypothalamus and nucleus accumbens subsequently increasing. By $\mathrm{E} 19, \mathrm{H}_{3}$ receptors are expressed within the cortical plate and deep cortical layers. $\mathrm{H}_{3}$ receptors have been shown to control the biosynthesis (Arrang et al., 1983; Arrang et al., 1987; Haas et al., 2008) and release of histamine as autoreceptors (Torrent et al., 2005; Arrang et al., 2007; Haas et al., 2008) and also function as hetero-receptors to regulate the release of other neurotransmitters including acetylcholine, glutamate, GABA, serotonin, and dopamine (Molina-Hernández et al., 2012). The $\mathrm{H}_{4}$ receptor is also coupled to intracellular $\mathrm{G}_{i}$ protein signaling (Gbahou et al., 2006) but little is known about $\mathrm{H}_{4}$ receptor expression in the developing brain and if and what role it may have in influencing neurodevelopment. There have been inconsistent findings regarding the expression of $\mathrm{H}_{4}$ receptors in the brain (Schneider and Seifert, 2016). Recent qRT-PCR experiments of striatal tissue of mice at different developmental periods (postnatal day 3 onward) showed no evidence for $\mathrm{H}_{4}$ receptor expression whereas $\mathrm{H}_{1}, \mathrm{H}_{2}$, and $\mathrm{H}_{3}$ receptor were detected from the first postnatal week onward (Han et al., 2020). 
However, some studies using other methods have detected expression in the amygdala, hippocampus, striatum, substantial nigra, thalamus, and hypothalamus (Connelly et al., 2009; Strakhova et al., 2009) and on some cell lines of microglia (Ferreira et al., 2012) and mast cells (Thangam et al., 2018).

\section{Histamine and Developing Neurons and Synapses}

Histamine has many different actions on the nervous system and has been shown to act at neuronal cells from the earliest developmental periods onward (see Table 1) (Molina-Hernández et al., 2012; Panula and Nuutinen, 2013; Panula et al., 2014). For example, histamine can increase the proliferation of rodent neural stem cells (NSC) or progenitors expressing histamine receptors during both embryonic and postnatal periods and increase the differentiation of adult NSCs into GABAergic neurons and the differentiation of fetal NSCs into glutamatergic FOXP2-positive neurons (Molina-Hernández and Velasco, 2008; Bernardino et al., 2012; Rodríguez-Martínez et al., 2012; Eiriz et al., 2014). Subsequently histamine also impacts the number and length of ramifications of neurites of developing neurons (Bernardino et al., 2012), suggesting it can modulate neuronal dendritic and axonal maturation. Recent studies have highlighted further roles for histamine during later periods of brain development impacting the formation of neuronal circuits in both the basal ganglia (Han et al., 2020) as well as the cortex (Prof. Molina-Hernandez - personal communication). The basal ganglia are a collection of subcortical nuclei that have crucial roles for motor behavior and cognition (Graybiel et al., 1994; Grillner et al., 2005). The striatum is the major input nucleus of the basal ganglia which both during early postnatal periods (Han et al., 2020) and in adulthood expresses high numbers of $\mathrm{H}_{1}, \mathrm{H}_{2}$, and $\mathrm{H}_{3}$ receptors (Haas and Panula, 2003), suggesting that histamine can act as a modulator of many processes in the basal ganglia (Bolam and Ellender, 2016). In both the striatum, and more generally in the brain, the first postnatal weeks are characterized by rapid increases in the number and strength of excitatory synaptic connections (Tepper et al., 1998; Kozorovitskiy et al., 2012; Peixoto et al., 2016; Krajeski et al., 2019; Peixoto et al., 2019) and these connections exhibit plastic changes (i.e., synaptic plasticity) which is crucial for their development and refinement (Calabresi et al., 1992a; Kreitzer and Malenka, 2008). Han et al. (2020) found that histamine could facilitate NMDA-receptor dependent synaptic plasticity at corticostriatal synapses during the second postnatal week, which was dependent on the $\mathrm{H}_{3}$ receptor, potentially through histamine-mediated dendritic depolarization (Calabresi et al., 1992b). Interestingly, histamine inhibited the NMDA-receptor dependent synaptic plasticity at older ages, again through the $\mathrm{H}_{3}$ receptor, which could indicate differential coupling of the $\mathrm{H}_{3}$ receptor to intracellular pathways depending on age (Drutel et al., 2001; Rapanelli et al., 2016). This suggests that histamine is key in gating corticostriatal synaptic plasticity at critical periods of remodeling and it remains to be investigated whether it might play a similar role in other developing neuronal circuits also. As discussed in greater detail in these Reviews
(Molina-Hernández et al., 2012; Panula and Nuutinen, 2013; Panula et al., 2014) the main impacts of histamine on neurons and synapses is the modulation of their excitability, often through action at $\mathrm{H}_{1}$ and/or $\mathrm{H}_{2}$ receptors (Munakata and Akaike, 1994; Prast et al., 1999; Ellender et al., 2011), as well as the modulation of release of various neurotransmitters through action at $\mathrm{H}_{3}$ receptors (Brown and Haas, 1999; Doreulee et al., 2001; MolinaHernández et al., 2001; Ellender et al., 2011). Most of these studies are performed in rodents during the first months of postnatal life, which corresponds to the second and third gestational trimester in humans (Romijn et al., 1991; Clancy et al., 2001). Indeed, as rodents are born at very immature stages of brain development their brains undergo most maturation postnatally suggesting findings have relevance for our understanding of human brain development.

Overall, histamine is an active neuromodulator in the developing brain acting at many developing cells and structures suggesting it may have an important role in brain development. Interestingly, although many of these cell express histamine receptors during early development, often the neuronal histaminergic afferents (e.g., from the TMN) might not be present yet (Auvinen and Panula, 1988; Han et al., 2020), suggesting that other histaminergic sources could be important during specific periods of development. As we will further outline below histaminergic dysregulation has been implicated in several neurodevelopmental (Ercan-Sencicek et al., 2010; Stevenson et al., 2010; Fernandez et al., 2012; Karagiannidis et al., 2013; Baldan et al., 2014; Wright et al., 2017) and a range of neuropsychiatric disorders (Shan et al., 2015).

\section{HISTAMINE AND NEURODEVELOPMENTAL DISORDERS}

Neurodevelopmental disorders (NDDs) comprise a heterogeneous group of highly heritable medical conditions that principally affect social communication, language, attention, impulsivity, learning, perception and motor coordination. They can frequently co-exist, persisting from childhood to adulthood with adverse medical and psychosocial outcomes on both the individual and their family (Jalenques et al., 2017). The clinical features of NDDs are thought to result, at least in part, from aberrant formation of key neuronal circuits during early periods of neurodevelopment, which can have lifelong effects. A growing body of literature implicates histamine dysregulation in NDDs including Tourette's syndrome (TS), autism spectrum disorders (ASD), attention deficit hyperactivity disorder (ADHD), and schizophrenia and is highlighted in further detail below (see also Table 2).

\section{Tourette's Syndrome}

Tic disorders include transient and chronic tic disorders, as well as TS that is characterized by both vocal and motor tics (Robertson, 2000). This group of neurodevelopmental disorders is typically diagnosed in childhood, with a childhood prevalence of approximately $0.6 \%$ of the population (Cleaton and Kirby, 2018). TS has numerous pre- and perinatal 
TABLE 1 | Effect of histamine on neurons, microglia, astrocytes and mast cells during early brain development.

\begin{tabular}{ll}
\hline Effect of histamine \\
\hline Neurons \\
Increased neural stem cell differentiation into GABAergic (adult) or glutamatergic (fetal) neurons via \\
$\mathrm{H}_{1}$ receptors. \\
Neural stem cell proliferation, apoptosis and decreased glial cell differentiation within the \\
neuroepithelium of the cortex via $\mathrm{H}_{2}$ receptors. \\
Modulation of synaptic plasticity and neural circuits. \\
Increased ACh release from striatal cholinergic interneurons via $\mathrm{H}_{1}$ or $\mathrm{H}_{2}$ receptors. \\
Inhibition of GABA release from spiny projection neurons in the striatum via $\mathrm{H}_{3}$ receptors. \\
Inhibition of glutamate release from synaptosomes. \\
Inhibition of glutamate release from cortical afferents to striatum. \\
Facilitating synaptic plasticity at corticostriatal synapses from the second postnatal week onward \\
via $\mathrm{H}_{3}$ receptors. \\
Facilitating long-term potentiation in the CA1 of the hippocampus via $\mathrm{H}_{1}$ and $\mathrm{H}_{2}$ receptors.
\end{tabular}

Microglia Microglia express all four subsets of histamine receptor.

Histamine can induce migration of microglia though $\mathrm{H}_{4}$ receptor activation.

Histamine can induce both pro- and anti-inflammatory response from microglia via $\mathrm{H}_{1}$ and $\mathrm{H}_{4}$ receptors.

Promote phagocytosis via $\mathrm{H}_{1}$ receptor activation and the production of reactive oxygen species and prostaglandin E2.

Hdc knockout $(\mathrm{KO})$ mice have a normal number of microglia but with reduced ramifications, reduced IGF-1 expression and reduced expression of $\mathrm{H}_{4}$ receptor.

Pro-inflammatory microglial response to challenge with LPS was greater in Hdc KO mice.

$\mathrm{H}_{3}$ receptor mediated autocrine and paracrine signaling has also been shown to inhibit microglial chemotaxis and phagocytosis along with inhibiting LPS-induced cytokine production.

Astrocytes

The $\mathrm{H}_{1}, \mathrm{H}_{2}$, and $\mathrm{H}_{3}$ receptors have been consistently shown to be expressed on astrocytes.

$\mathrm{H}_{3}$ receptor expression may be restricted to certain brain regions and may vary depending on the species that is studied.

Elicit glutamate release in an $\mathrm{H}_{1}$ receptor-dependent and concentration-dependent manner. Astrocytic $\mathrm{Ca}^{2+}$ signaling and subsequent astrocytic glutamate release was highly sensitive to histamine and concentration-dependent acting through the $\mathrm{H}_{1}$ receptor. Astrocytic cAMP levels increased in response to histamine, it remains unclear if and what role this has in gliotransmitter release.

Histamine can act synergistically with pro-inflammatory cytokines such as IL-1 and IL-6 to modulate astrocytic release of neurotrophins such as NGF.

Histamine selectively upregulates the expression of $\mathrm{H}_{1}, \mathrm{H}_{2}$, and $\mathrm{H}_{3}$ receptors, stimulated the synthesis of astrocytic GDNF and concentration-dependent inhibition of the production of pro-inflammatory cytokines, TNF- $\alpha$ and IL-1 $\beta$.

Mast cells

Mast cells are a non-neuronal source of histamine that can be released upon degranulation.

Mast cell expression of $\mathrm{H}_{1}$ and $\mathrm{H}_{4}$ receptors is implicated in type 1 hypersensitivity reactions. However, their expression in brain mast cells is not confirmed.

Co-cultures of mast cells with astrocytes has been shown to lead to the release of histamine and leukotrienes via CD40-CD40L interactions.

The mast cell degranulator, $\mathrm{C} 48 / 80$ can trigger hypothalamic microglial activation and the release of IL-6 and TNF- $\alpha$.

Mast cell activation with estradiol stimulates microglial activation and subsequent prostaglandin release and that was associated with increased dendritic spine density and higher amounts of the dendritic spine protein, spinophilin.

Mast cells strongly adhere to hippocampal neurons via cell adhesion molecule $1 \mathrm{~d}$.

Neuropeptides released from neurites bind directly bind to mast cells, altering their activation state.

Mast cell derived products may enter neurons via transgranulation, whereby mast cells are in direct contact with neurons and exocytosed mast cell granules are directly taken up by the adjacent neuron.

\section{References}

Molina-Hernández and Velasco, 2008; Bernardino et al., 2012

Molina-Hernández and Velasco, 2008; Bernardino et al., 2012; Rodríguez-Martínez et al., 2012

Prast et al., 1999

Ellender et al., 2011

Molina-Hernández et al., 2001

Doreulee et al., 2001; Ellender et al., 2011

Han et al., 2020

Brown et al., 1995; Dai et al., 2007; Haas et al., 2008; Chepkova et al., 2012

Dong et al., 2014a; Haas and Panula, 2016; Zhang et al., 2020

Ferreira et al., 2012; Dong et al., 2014a; Fang et al., 2020; Zhang et al., 2020

Rocha et al., 2016; Lenz et al., 2018

Frick et al., 2016

Frick et al., 2016

lida et al., 2015

Jurič et al., 2016; Karpati et al., 2018

Hosli and Hosli, 1984; Hosli et al., 1984

Karpati et al., 2018

Lipnik-Štangelj and Čarman-Kržan, 2005; Lipnik-Stangelj and Carman-Krzan, 2006; Ales et al., 2008

Xu et al., 2018

Katoh et al., 2001; Haas et al., 2008

Thangam et al., 2018

Kim et al., 2010

Dong et al., 2017

Lenz et al., 2018

Hagiyama et al., 2011

Kulka et al., 2008

Wilhelm et al., 2005

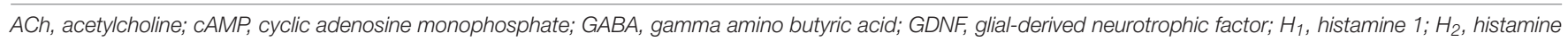

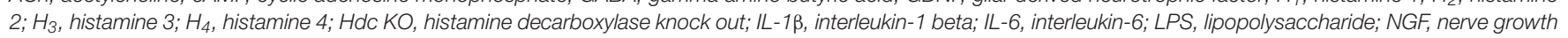
factor; NSC, neural stem cells; TNF- $\alpha$, tumor necrosis factor alpha. 
TABLE 2 | The role of histamine in the aetiology of neurodevelopmental disorders.

\begin{tabular}{|c|c|c|}
\hline & Role of histamine & References \\
\hline \multirow[t]{6}{*}{ Tourette's syndrome } & $\begin{array}{l}\text { A rare nonsense mutation in the gene encoding Histidine decarboxylase (Hdc), the } \\
\text { rate-limiting enzyme in histamine synthesis, has been implicated in a two-generation } \\
\text { pedigree }\end{array}$ & Ercan-Sencicek et al., 2010 \\
\hline & $\begin{array}{l}\text { There is a gene-dose dependent decrease in histamine concentration in the } \\
\text { hypothalamus, striatum and cortex, in mice that were heterozygous or knock out for } \\
\text { Hdc compared to wild type mice. }\end{array}$ & Baldan et al., 2014 \\
\hline & $\begin{array}{l}\text { Hdc KO mice exhibit repetitive movements in response to acute stress and } \\
\text { psychostimulant challenge that were mitigated with pre-treatment with the dopamine } 2 \\
\text { receptor antagonist, haloperidol. }\end{array}$ & Baldan et al., 2014 \\
\hline & $\begin{array}{l}\text { Dopamine levels and } \mathrm{D}_{2} / \mathrm{D}_{3} \text { receptor expression are increased in Hdc } \mathrm{KO} \text { mice, } \\
\text { suggesting that there may be an interaction between histaminergic and dopaminergic } \\
\text { signaling in mediating the symptoms of Tourette syndrome. }\end{array}$ & Baldan et al., 2014 \\
\hline & $\begin{array}{l}\mathrm{H}_{3} \text { receptors are upregulated in } \mathrm{Hdc} \mathrm{KO} \text { mice, and chemogenetic activation of these } \\
\text { receptors in the dorsal striatum can precipitate stereotypies. }\end{array}$ & Rapanelli et al., 2017 \\
\hline & $\begin{array}{l}\text { Histamine infusion may reduce the concentration of dopamine in the striatum by } \\
\text { agonizing } \mathrm{H}_{3} \text { heteroreceptors on dopaminergic afferents. }\end{array}$ & Schlicker et al., 1993 \\
\hline \multirow[t]{2}{*}{$\begin{array}{l}\text { Autism spectrum } \\
\text { disorders }\end{array}$} & $\begin{array}{l}\text { Histamine dysregulation may have a role in mediating autism spectrum disorder } \\
\text { phenotype with altered expression of key histamine signaling genes } H N M T, H R H 1 \text {, } \\
H R H 2 \text {, and } H R H 3 \text { in post-mortem brains of patients with ASD. }\end{array}$ & Wright et al., 2017 \\
\hline & $\begin{array}{l}\mathrm{H}_{3} \text { receptor has been implicated in repetitive behavior-like pathology including } \\
\text { stereotypies that may be a feature of ASDs. }\end{array}$ & Rapanelli et al., 2017 \\
\hline \multirow{2}{*}{$\begin{array}{l}\text { Attention deficit } \\
\text { hyperactivity } \\
\text { disorder }\end{array}$} & $\begin{array}{l}\text { Methylphenidate, and atomoxetine may stimulate cortical histamine through enhanced } \\
\text { dopamine and noradrenaline transmission. }\end{array}$ & Horner et al., 2007 \\
\hline & Polymorphisms of the HNMT gene have been seen in those with ADHD. & Stevenson et al., 2010 \\
\hline \multirow[t]{4}{*}{ Schizophrenia } & $\begin{array}{l}\text { Elevated levels of the histamine metabolite tele-methylhistamine have been implicated in } \\
\text { schizophrenia, suggesting greater histamine release and turnover. }\end{array}$ & Prell et al., 1995, 1996 \\
\hline & $\begin{array}{l}\text { Adjunct use of the } \mathrm{H}_{2} \text { receptor antagonist, ranitidine, led to a significant but } \\
\text { non-sustained reduction in negative symptoms in people with schizophrenia. }\end{array}$ & Mehta and Ram, 2014 \\
\hline & $\mathrm{H}_{3}$ receptors are upregulated in the prefrontal cortex of people with schizophrenia. & Jin et al., 2009a \\
\hline & $\begin{array}{l}\mathrm{H}_{3} \text { receptor antagonists improved symptoms of cognitive impairment in animal studies } \\
\text { but this has so far not been translated to human studies. }\end{array}$ & $\begin{array}{l}\text { Pre-clinical studies: Southam et al., 2009; } \\
\text { Bardgett et al., 2010; Brown et al., } 2013 . \\
\text { Clinical trials: Haig et al., 2014; Jarskog } \\
\text { et al., } 2015\end{array}$ \\
\hline
\end{tabular}

$D_{2}$, dopamine 2; $D_{3}$, dopamine 3; $H_{1}$, histamine $1 ; H_{2}$, histamine 2; $H_{3}$, histamine 3; $H_{4}$, histamine 4; Hdc KO, histamine decarboxylase knock out; HRH1, histamine receptor $\mathrm{H1}$; $\mathrm{HRH} 2$, histamine receptor $\mathrm{H2}$; $H R H 3$, histamine receptor $\mathrm{H} 3$; $H N M T$, histamine $N$-methyltransferase.

environmental risk factors, including parental age and education, socioeconomic status, maternal hypertension, antenatal and perinatal complications, maternal smoking and alcohol exposure and severe psychosocial stress (Chao et al., 2014). This is alongside a heritability of approximately 58\% (Davis et al., 2013). Together these highlight the importance of embryogenesis and prenatal neurodevelopment in its pathophysiology. Tic disorders are commonly seen along with other comorbid mental disorders such as obsessive-compulsive disorder (OCD) and ADHD (Freeman et al., 2000). The motor and vocal tics and increased repetitive behaviors seen in TS are thought to arise from aberrant neural activity in the cortico-basal ganglia circuitry (Albin and Mink, 2006), specifically in the striatum (Jeffries et al., 2002). Histamine receptors are markedly expressed in striatum, suggesting histamine has an important role in modulation of this circuit (Bolam and Ellender, 2016; Haas and Panula, 2016; Han et al., 2020).

The hypothesis that histamine deficiency is implicated in the pathophysiology of TS stems from a seminal study in the New England Journal of Medicine by Ercan-Sencicek et al. (2010) at Yale University. This study identified a rare nonsense mutation in the gene encoding $H d c$, the rate-limiting enzyme in histamine synthesis, as being associated with TS in a twogeneration pedigree (Ercan-Sencicek et al., 2010). Subsequent genetic studies provided further evidence that dysregulated histaminergic signaling has a causal role in TS in humans through copy number variations and over-transmission of single nucleotide polymorphisms (Fernandez et al., 2012; Karagiannidis et al., 2013). The implication of the $H d c$ gene as a rare mutation has led to a monogenic causal model of TS in the form of the $H d c$ knock out (KO) mouse that is both validated and is translatable between humans and mice (Baldan et al., 2014). There is a gene copy-number dependent decrease in histamine concentration in the hypothalamus, striatum and cortex, in mice that were heterozygous or knock out for $H d c$ compared to wild type mice (Baldan et al., 2014). They did not exhibit tic-like hyperkinetic movements at rest. However, repetitive movements such as stereotypies (repetitive focused sniffing and orofacial movements) or excessive grooming, were elicited in response to acute stress and/or psychostimulant challenge that 
were mitigated with pre-treatment with the dopamine $2\left(\mathrm{D}_{2}\right)$ receptor antagonist, haloperidol (Baldan et al., 2014). This was compared to increased locomotion in wild type mice. Both dopamine levels and $\mathrm{D}_{2} / \mathrm{D}_{3}$ receptor expression are increased in $\mathrm{Hdc} \mathrm{KO}$ mice, suggesting that there may be an interaction between histaminergic and dopaminergic signaling in mediating the symptoms of TS (Baldan et al., 2014). Indeed, $\mathrm{H}_{3}$ receptors are found to be upregulated in $\mathrm{Hdc} \mathrm{KO}$ mice, and chemogenetic activation of these receptors in the dorsal striatum can precipitate stereotypies (Rapanelli et al., 2017) suggesting that histamine, and specifically the $\mathrm{H}_{3}$ receptor in the dorsal striatum, are contributing to the repetitive movements that are a prominent feature of TS. Histamine infusion may reduce the concentration of dopamine in the striatum by agonizing $\mathrm{H}_{3}$ heteroreceptors on dopaminergic afferents thereby reducing onward dopaminergic signaling (Schlicker et al., 1993). However, variants in the Hdc gene do appear to be rare and they have not been implicated in other cases of TS in those of Caucasian and Asian origin (Lei et al., 2012) suggesting other causes. For example, Abelson et al. (2005) identified rare mutations in the Slit and Trk-like family member 1 (SLITRK1) gene in 174 unrelated TS probands/subjects. Sanger sequencing has since confirmed that rare variants in these genes are implicated in the susceptibility to TS in both a European and Canadian cohort (Alexander et al., 2016). This suggests that both can have functional roles in the pathophysiology of TS, which warrants further investigation and furthermore highlights the genetic complexity underpinning the etiology of TS.

\section{Autism Spectrum Disorder}

Autism spectrum disorder (ASD) is a common NDD, with an estimated prevalence of $1-2 \%$ in the general population (Baird et al., 2006; Brugha et al., 2011) and a heritability of $50-60 \%$ (Buehler, 2011; Yoo, 2015). It is often diagnosed alongside multiple comorbid diagnoses of mental illness including intellectual disability (Matson and Shoemaker, 2009), TS (Kalyva et al., 2016), and schizophrenia (De Giorgi et al., 2019). ASD is characterized by impairments in social interactions and communication skills and stereotypic and restricted, repetitive behaviors and interests. It is also commonly associated with literal thinking, a lack of central coherence and difficulties with emotional regulation. The term ASD encompasses a range of presentations that in previous classification systems have been described as classical autism, pervasive developmental disorder, Asperger syndrome and atypical autism. ASD shares genetic risk factors with TS (Clarke et al., 2012; Fernandez et al., 2012) and there appears to be a marked overlap in appearance and underlying pathophysiology between stereotyped, repetitive behaviors in ASD, tics in TS and compulsions in OCD.

The etiology of ASD remains unclear. However, abnormalities in cortico-striatal circuitry have been implicated (Prat et al., 2016), as has dysregulation of several neurotransmitter systems including serotonin, acetylcholine, dopamine, GABA and glutamate (Eissa et al., 2018a). Histamine dysregulation may have a role in mediating these abnormalities with increased expression of the gene set HNMT, HRH1, HRH2, and HRH3 seen in post-mortem brains of patients with ASD (Wright et al., 2017). In addition, the $\mathrm{H}_{3}$ receptor has been implicated in repetitive behavior-like pathology (Rapanelli et al., 2017). Indeed, histamine can act as a modulator of release of the aforementioned implicated neurotransmitters (MolinaHernández et al., 2012). As mentioned above histamine can also impact the differentiation of embryonic NSCs into glutamatergic FOXP2-positive neurons. FOXP2 is a transcription factor, the expression of which influences the formation of deep cortical layers in the developing brain (Gaspard et al., 2008) with mutations resulting in abnormalities in speech and language development (Lai et al., 2001; Takahashi et al., 2003), a common feature of NDDs such ASD.

\section{Attention Deficit Hyperactivity Disorder}

Attention deficit hyperactivity disorder (ADHD) is an NDD characterized by inattentive, hyperactive and impulsive symptoms (Luo et al., 2019). Dysregulation of dopaminergic and noradrenergic transmission has been implicated in its pathophysiology. Pharmacological treatment with stimulant and non-stimulant medications results in an increase in transmission of these catecholamines in regions of the brain associated with cognition and attention (Wilens, 2006). Histamine can also increase alertness and attention, with blockade of the $\mathrm{H}_{3}$ autoreceptor shown to increase histamine release and improve cognitive function (Leurs et al., 2005). The stimulant drug, methylphenidate, and non-stimulant noradrenaline reuptake inhibitor, atomoxetine, have been shown to stimulate cortical histamine release without any affinity for the $\mathrm{H}_{3}$ receptor (Horner et al., 2007). This may indicate that the increased release of histamine is secondary to enhanced dopamine and noradrenaline transmission. Polymorphisms of the HNMT gene have been seen in those with ADHD (Stevenson et al., 2010). Together, this data suggest that altered histamine transmission may be implicated in the pathophysiology of ADHD.

\section{Schizophrenia}

Schizophrenia is severe mental illness with a lifetime prevalence of $0.7 \%$ (Saha et al., 2005). It is a chronic psychotic disorder characterized by positive symptoms such as hallucinations and delusions, negative symptoms such as social withdrawal, anhedonia and avolition, and cognition impairments. It is associated with high morbidity and mortality. While antipsychotic drugs remain the mainstay of treatment, a substantial proportion of people do not have an adequate clinical response to such medications (Howes et al., 2012a,b), necessitating a better understanding of the underlying neurobiology and the development of new approaches to treatment. The most influential theories on the neurobiology of schizophrenia are that of the dopamine and glutamate hypotheses (Howes et al., 2015). Excess dopamine transmission in the mesolimbic pathway has been associated with the positive symptoms, specifically an increase in the capacity for dopamine synthesis and release (Howes et al., 2013) and greater $D_{2}$ receptor density (Howes et al., 2012a). However, the direction of causality is yet to be established. In addition, a substantial proportion of patients do not have a therapeutic response to dopamine modulating pharmacotherapies (Mortimer et al., 2010). The glutamate hypothesis of schizophrenia is based on the 
association of the disorder with NDMA receptor hypofunction and the overlap in clinical presentation with NMDA encephalitis (Howes et al., 2015). Nonetheless the precise mechanism by which altered glutamate transmission may lead to the symptoms of schizophrenia remains unclear nor are there any glutamate receptor modulating pharmacotherapies established for clinical use.

Abnormal histamine transmission has also been associated with schizophrenia. Indeed, elevated levels of the histamine metabolite tele-methylhistamine suggest greater histamine release and turnover (Prell et al., 1995, 1996). $\mathrm{H}_{1}$ receptor expression in cholinergic neurons in the basal forebrain is lower in patients with schizophrenia and deletion of $\mathrm{H}_{1}$ receptors in these neurons in mice results in a sensorimotor gating deficit, social impairment and anhedonia-like behavior (Cheng et al., 2021). $\mathrm{H}_{2}$ receptor antagonism has been shown to have beneficial effects in schizophrenia, including a reduction in both positive and negative symptoms (Meskanen et al., 2013; Mehta and Ram, 2014). Moreover, $\mathrm{H}_{3}$ receptors are upregulated in the prefrontal cortex of people with schizophrenia (Jin et al., 2009a), with initial animal studies demonstrating that $\mathrm{H}_{3}$ receptor antagonists improved symptoms of cognitive impairment (Southam et al., 2009; Bardgett et al., 2010; Brown et al., 2013). However, this has so far not been translated to humans with clinical trials showing no improvement in cognitive symptoms with various $\mathrm{H}_{3}$ receptor antagonists (Haig et al., 2014; Jarskog et al., 2015).

Together these findings would suggest that histamine is key in the normal physiological processes of the brain and is dysregulated in a variety of NDDs likely resulting in aberrant activity and/or development of key neuronal circuits. However, exactly how histamine dysregulation may alter neuronal circuitry and whether it is through a direct effect on neurons and/or indirectly through other cells often remains unclear. We will next explore how histamine is able to interact with some of the non-neuronal cells found in the brain.

\section{HISTAMINE AND NON-NEURONAL CELLS}

Histamine can act as a local (paracrine) neurotransmitter as well as a modulator of the immune system. Several studies have shown that histamine can mediate a pro- or anti-inflammatory response depending on the cytokines produced and the effect of the local environment. These include pro-inflammatory cytokines such as interleukin 1-beta (IL-1 $\beta$ ) and tumor necrosis factor alpha (TNF- $\alpha$ ) and anti-inflammatory cytokines such as transforming growth factor beta (TGF- $\beta$ ) (Johnson and Krenger, 1992; Skaper et al., 2001; Dong et al., 2014a; Zhang et al., 2020). The effect of the immune system on neurodevelopment is therefore complex, promoting healthy neurodevelopment in some circumstances while being pathological in others. To complicate matters further, several cytokines, most notably interleukin 6 (IL-6), have pleiotropic functions on neuronal function (Xing et al., 1998; Scheller et al., 2011) whereby altering their precise signaling pathway may have varied effects on neurodevelopment that are yet to be fully understood. We have discussed the roles for histamine in the early development of key neural circuits. It may be that the altered development of these circuits in NDDs is compounded through neuroinflammation that can be modulated by histamine in the brain. This complex action likely involves multiple cell types (see Figure 2), including astrocytes, microglia; the resident macrophages of the brain, and mast cells; immune cells that are an important non-neuronal source of histamine. The role of these cells in neuroinflammation and neurodevelopment and the possible influence of histamine on these processes will now be discussed (see also Table $\mathbf{1}$ ).

\section{Prenatal and Postnatal Neuroinflammation and Neurodevelopment}

Neurodevelopment is a highly organized process, beginning with neurogenesis and migration of young neurons followed by synaptogenesis, synaptic pruning and myelination (Knuesel et al., 2014) (see Figure 1). Every step in the formation of neuronal circuits can be disrupted by inflammation of the developing brain (Knuesel et al., 2014). Indeed, several NDDs have been associated with pre- and/or early postnatal neuroinflammation, including ASD, schizophrenia, cerebral palsy and epilepsy (Rodriguez and Kern, 2011; Knuesel et al., 2014; Kuban et al., 2015; Kim et al., 2017; Allswede and Cannon, 2018; Reed et al., 2020).

Prenatal inflammation may be mediated though increased maternal immune activation (Ji-Xu and Vincent, 2020) that has been associated with adverse neurodevelopment, particularly in the late first and early second trimester - a time at which the fetal immune system is still poorly developed (Knuesel et al., 2014). This activation of the maternal immune system may be in response to a diverse range of infections (e.g., pneumonia, sinusitis, tonsillitis, and toxoplasmosis), which may confer an increased risk of neuropsychiatric disorders (Patterson, 2009; Knuesel et al., 2014). For example, a recent study investigated the potential mechanisms underpinning this, finding that maternal immune activation can lead to an interleukin 17a (IL-17a)-dependent stress response that reduced global mRNA translation. Interestingly, this occurred in male rodents only and blockade of this stress response ameliorated any behavioral abnormalities associated with maternal immune activation, suggesting a sex-specific effect of maternal immune activation on neuroinflammation and neurodevelopment (Kalish et al., 2021). Indeed, autoimmune disorders (Patel et al., 2020) can lead to a similar sex-specific immune response. Furthermore, maternal neuronal autoantibodies have been associated with NDDs such as ASD (Dalton et al., 2003; Giannoccaro et al., 2019). For example, the contactin-associated protein-2 (CASPR2) has been identified as a specific target for maternal autoantibodies that in turn, can alter synaptic development in utero with lifelong behavioral abnormalities, including impaired social interactions and increased repetitive behaviors (Coutinho et al., $2017 a, b, c)$. There are therefore multiple potential precipitants that activate the maternal immune response and confer an increased risk of NDDs.

Postnatal inflammatory illnesses are also associated with perinatal brain pathology. Indeed, precipitants such as necrotizing enterocolitis and bacteremia in neonates have 


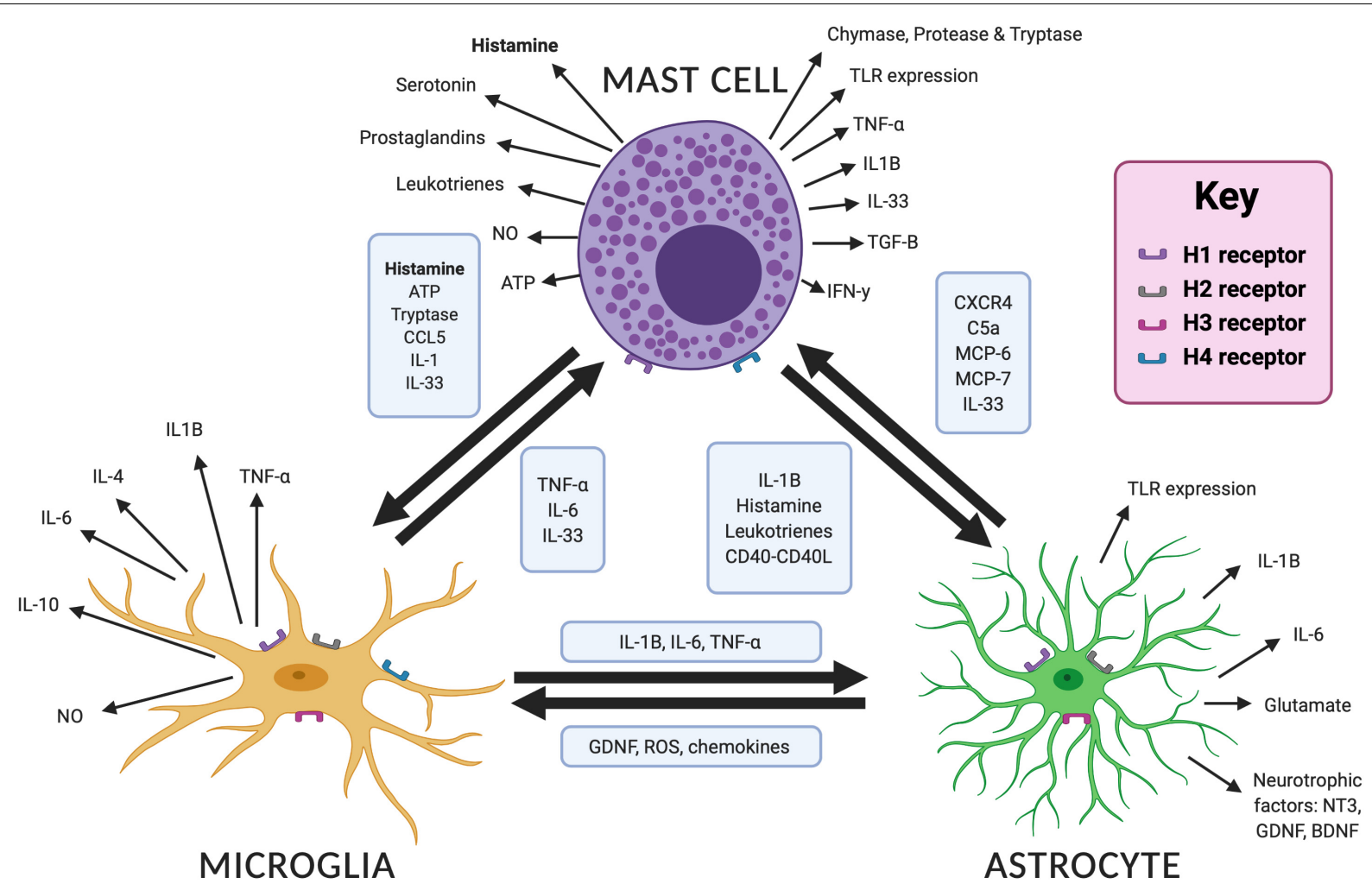

FIGURE 2 | Interactions and mediators between mast cells, microglia and astrocytes in the brain. Bidirectional interactions are demonstrated between each cell type with the mediators involved in boxes. Different mediators are released in response to cellular activation, which are shown for each cell type. Image created with BioRender.com. ATP, adenosine triphosphate; BDNF, brain derived neurotrophic factor; CCL5, C-C motif chemokine ligand 5; C5a, complement 5a; CXCR4, CXC chemokine receptor 4; GDNF, glial derived neurotrophic factor; IL, interleukin; MCP, mast cell protease; NO, nitric oxide; NT3, neurotensin 3; ROS, reactive oxygen species; TLR, toll like receptor; TNF- $\alpha$, tumor necrosis factor alpha.

been identified as risk factors for white matter damage and adverse neurodevelopmental outcomes at 2 years old (O'shea et al., 2013). However, postnatal inflammation itself may also stem from a prenatal antecedent. The Extremely Low Gestational Age Newborn (ELGAN) Study considered the risk of several prenatal antecedents of inflammation and subsequent neurodevelopment, including fetal growth restriction, maternal obesity, placental microorganisms and socioeconomic adversity. Interestingly, it found that indicators of socioeconomic disadvantage associated with an increased risk of systemic postnatal inflammation, suggesting that prenatal inflammation may persist into the postnatal period. This was also supported by the study of Yanni et al. (2017) who found that the risk of adverse neurodevelopment is heightened further when evidence of preand post-natal inflammation are seen together. Specifically, placental inflammation followed by persistent elevation of proinflammatory cytokine such as IL- 6 and TNF- $\alpha$ was associated with a heightened risk of cerebral palsy and microcephaly at 2 years old in preterm newborns (Yanni et al., 2017).

While both antenatal and postnatal inflammation alone has been associated with adverse neurodevelopment, the maternal immune response alone has not been shown to directly cause NDDs (Bennet et al., 2018). It may be that exposure to more than one risk factor is needed for phenotypic expression, with maternal inflammation priming the individual for other genetic or environmental triggers. This hypothesis has been directly tested in animal studies where induction of maternal inflammation with lipopolysaccharide results in a hypofunction of the NMDA-receptor and loss of hippocampal synaptic plasticity. When this is combined with an environmental stressor, e.g., restraint, this led to the phenotypic expression of various ASD-related behaviors (Reisinger et al., 2015). Neuroinflammation may therefore increase the vulnerability of the brain to a second insult in the pathophysiology of NDDs.

\section{What Are Microglia?}

Microglial cells are the antigen presenting cells of the CNS and are key mediators of neuroinflammation (Kettenmann et al., 2011). They have a role in surveillance and phagocytosis of cellular debris (Sierra et al., 2013) and maintenance of brain function and are thought to regulate many processes including neurogenesis, synaptic plasticity and synaptic pruning (Aloisi, 2001; Tremblay et al., 2010; Ji et al., 2013; Schafer and Stevens, 2013; Zhan et al., 2014; Wu et al., 2015; Bar and Barak, 2019). They are derived from primitive myeloid progenitor cells and migrate into the CNS during embryogenesis, appearing before E8 in mice and 4.5-5 weeks in humans (Lichanska and Hume, 2000; Ginhoux et al., 2010), and increase 
in numbers rapidly from E16 onward in mice (Swinnen et al., 2013) and are functionally heterogeneous (Smolders et al., 2019; Mendes and Majewska, 2021). Microglial progenitors infiltrate the CNS before the vasculature is maturely formed, either migrating though the ventricular walls or through the meninges (Ginhoux et al., 2010; Swinnen et al., 2013; Reemst et al., 2016). Migration and distribution may also be further regulated by direct neuronal-microglial interactions though the chemokine CX3CL1, otherwise known as Fractalkine, and its corresponding receptor expressed on the microglia (Paolicelli et al., 2011). They then disperse in non-uniform manner, comprising $0.5-16.6 \%$ of the cell population depending on the region of the adult brain (Lawson et al., 1992) and differentiate to help regulate neurodevelopment, monitoring and maintaining synapses in the healthy, uninjured brain (Aloisi, 2001; Bar and Barak, 2019). We would direct readers to some excellent review articles on the role of microglia on neurodevelopment (Cowan and Petri, 2018; Coomey et al., 2020; Thion and Garel, 2020).

\section{Microglia and Neuroinflammation}

Increased microglial-mediated neuroinflammation has been seen in numerous NDDs, including ASD (Morgan et al., 2010; Tetreault et al., 2012; Suzuki et al., 2013; Gupta et al., 2014; Lee et al., 2017), schizophrenia (Garey, 2010; Sellgren et al., 2019; Chini et al., 2020), ADHD (Anand et al., 2017), and TS (Lennington et al., 2016). Microglia in the developing brain are also sensitive to external perturbations such as maternal infections (Smolders et al., 2015; Bernstein et al., 2016; Rosin et al., 2021a; Rosin et al., 2021b). Microglia are thought to initiate an immune response to protect the brain, but altered microglial activity has also been implicated in disorders of neurodevelopment and neurodegeneration through an upregulation of neuroinflammation (Kettenmann et al., 2011; Salter and Stevens, 2017). The precise mechanisms how a microglial bias toward pro- or anti-inflammatory cytokine production can affect neurodevelopment and pathological states remains incompletely understood. As further outlined below histamine has been shown to trigger both anti-inflammatory and pro-inflammatory responses from the microglia (Biber et al., 2007; Zhang et al., 2020). An appreciation of the role of the microglia in neuroinflammation and neurodevelopment and their regulation by histamine is therefore an exciting prospect into understanding the pathophysiology of a range of neurodevelopmental disorders.

\section{Microglia and NDDs}

Microglia have been implicated in neurodevelopmental disorders such as ASD and schizophrenia, both of which are characterized as having deficits in synaptic pruning, synaptogenesis and altered circuit development. Proposed mechanisms include those mediated through the action of complement proteins such as C1q, C3, and C4 (Stevens et al., 2007; Paolicelli et al., 2011; Fu et al., 2012; Ramaglia et al., 2012; Schafer et al., 2012) and/or altered release of brain derived neurotrophic factor (BDNF) with deficits in AMPA and NMDA receptor-mediated long-term potentiation (LTP) and synaptic remodeling (Parkhurst et al., 2013) (see Figure 3). Moreover, HoxB8 knock out mice, a gene expressed by a subpopulation of microglia, has been associated with increased grooming behaviors similar in nature to TS, OCD and ASD (Chen et al., 2010) and as seen in the Hdc KO model of TS. These behaviors are then attenuated by repopulation of the brain with wild type microglia (Chen et al., 2010). Lastly, there is emerging evidence on the importance of CD4+ T cells in microglial activation in facilitating normal neurodevelopment (Pasciuto et al., 2020). Although not discussed here in detail $\mathrm{T}$ cells are interesting in that they are able to control brain inflammatory responses through histaminergic signaling (Jutel et al., 2001; del Rio et al., 2012; Korn and Kallies, 2017) and could facilitate cross-talk between the brain and the periphery (Rustenhoven et al., 2021) in conjunction with other factors (Salvador et al., 2021).

\section{Histamine's Regulation of Microglia}

Microglia have been shown to express all four subsets of histamine receptor (Dong et al., 2014a; Haas and Panula, 2016; Zhang et al., 2020), which can differentially affect their behavior. For example,Frick et al. (2016) undertook one of the first in vivo studies on the role of histamine in microglial activation. The group used immunohistochemistry to assess the effect of either histamine deficiency ( $H d c$ KO mouse model) or histamine stimulation in wild type mice on microglia. Histamine was shown to regulate microglia via the $\mathrm{H}_{4}$ receptor. $\mathrm{Hdc} \mathrm{KO}$ mice have a normal number of microglia but with reduced ramifications, reduced insulin-like growth factor-1 (IGF1) expression and reduced expression of $\mathrm{H}_{4}$ receptor that may indicate impairment in histaminergic regulation of microglia. Similar findings occurred by selective removal of histaminergic neurons in the TMN of the hypothalamus. IGF-1 expressing microglia are induced by cytokines released from $\mathrm{T}$ helper 2 cells, which may be neuroprotective, promoting neurogenesis. Furthermore, the pro-inflammatory microglial response to challenge with lipopolysaccharide (LPS) was greater in $\mathrm{Hdc} \mathrm{KO}$ mice. This may indicate that a genetic predisposition such as histamine deficiency may increase the brain's vulnerability to proinflammatory insults in neuropsychiatric disorders such as TS. Indeed exogenous histamine was able to reduce LPS induced inflammation in the hippocampus (Saraiva et al., 2019).

Interestingly, in vitro studies have shown both pro- and anti-inflammatory effects of histamine on microglial function (Biber et al., 2007). For example, histamine can reduce proinflammatory cytokine production such as IL-1 $\beta$ in response to mediators such as LPS as well modulate overall microglial motility (Ferreira et al., 2012). This may indicate an antiinflammatory function of histamine on the microglia. However, in contrast to this, microglial secretion of the pro-inflammatory cytokines TNF- $\alpha$ and IL- 6 is triggered by histaminergic stimulation of the $\mathrm{H}_{1}$ and $\mathrm{H}_{4}$ receptors (Dong et al., 2014a; Zhu et al., 2014). Specifically, Zhang et al. (2020) found that histamine could induce microglial activation and the production of the pro-inflammatory cytokines TNF- $\alpha$ and IL- $1 \beta$ that was partially negated with $\mathrm{H}_{1}$ and $\mathrm{H}_{4}$ receptor antagonists and stimulated with $\mathrm{H}_{1}$ and $\mathrm{H}_{4}$ receptor agonists. On the other hand, $\mathrm{H}_{2}$ and $\mathrm{H}_{3}$ receptor antagonists led to significant increases in TNF- $\alpha$ and IL- $1 \beta$, and $\mathrm{H}_{2}$ and $\mathrm{H}_{3}$ receptor agonists significantly increased 


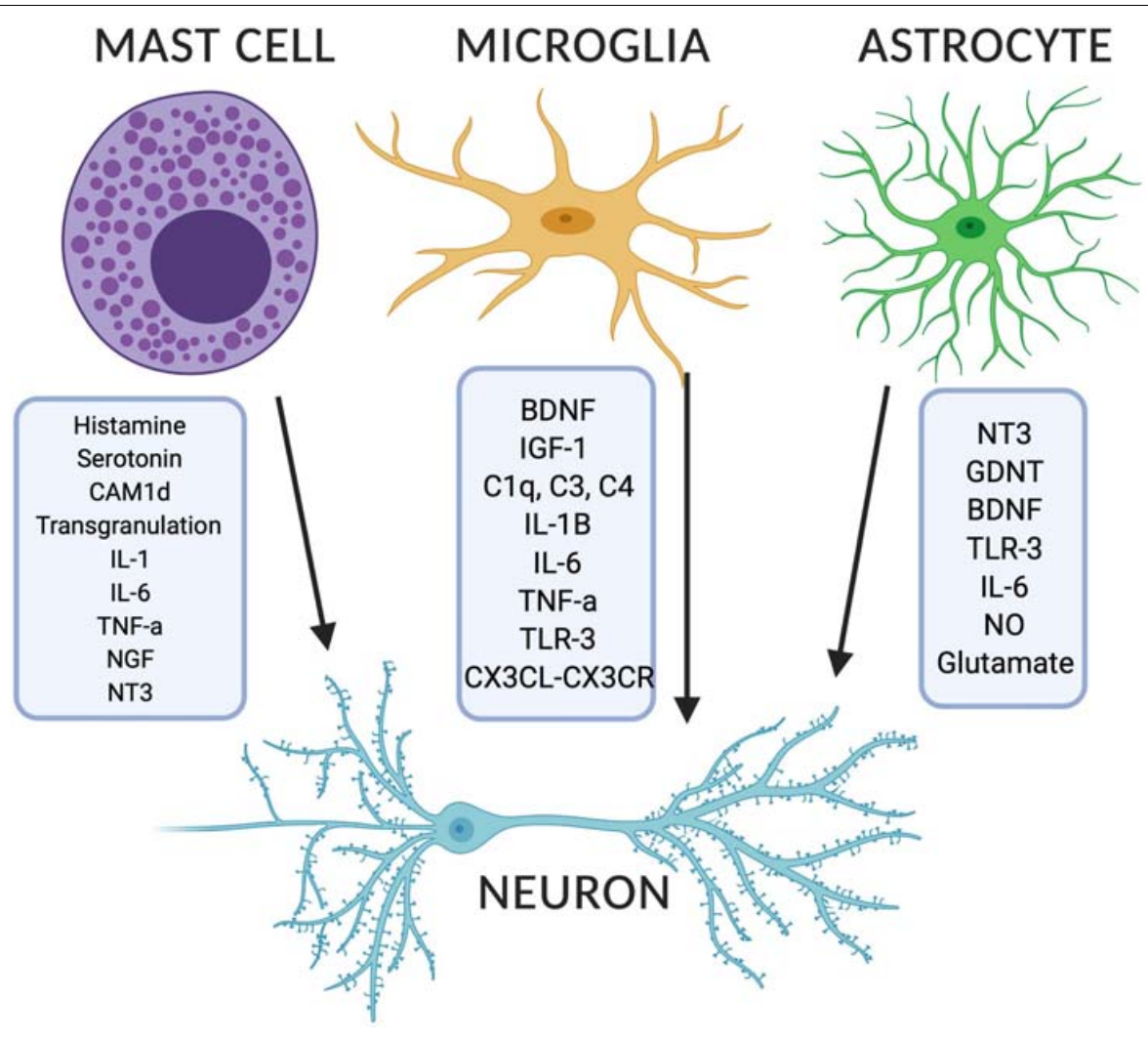

FIGURE 3 | Released modulators from mast cells, microglia and astrocytes can impact on developing neurons in the brain. Image created with BioRender.com. BDNF, brain derived neurotrophic factor; CX3CL, CX3C chemokine ligand 1; CX3CL, CX3C chemokine receptor; GDNF, glial derived neurotrophic factor; IGF-1, insulin-like growth factor 1; IL, interleukin; NGF, nerve growth factor; NO, nitric oxide; NT3, neurotensin 3; TLR, toll like receptor; TNF- $\alpha$, tumor necrosis factor alpha.

the release of the anti-inflammatory cytokine interleukin-10 (IL10). This is further supported by both Chen et al. (2020) who found that $\mathrm{H}_{2}$ and $\mathrm{H}_{3}$ receptor agonism inhibited laparotomyor LPS-induced microglial activation, pro-inflammatory cytokine production and cognitive decline and by Fang et al. (2020) whereby $\mathrm{H}_{4}$ receptor antagonism reduced microglial activation and TNF- $\alpha$ release in a rat model of Parkinson's disease. Along with histamine's ability to induce microglial activation and the subsequent release of both anti- and pro-inflammatory factors, it can also promote phagocytosis via $\mathrm{H}_{1}$ receptor activation and the production of reactive oxygen species (Rocha et al., 2016) and prostaglandin E2 (Lenz et al., 2018).

Overall, these findings highlight the pleiotropic nature of the microglia in mediating their immune response and suggest potential roles for histamine in regulating microglial-mediated inflammation. What remains poorly studied though, is which sources of histamine within the CNS may contribute to both microglia-mediated neuroinflammation and altered neurodevelopment.

\section{What Are Astrocytes?}

Astrocytes are the most numerous cell type found within the CNS, forming complex networks with neuronal and nonneuronal cells alike. They are dynamic cells that have a wide range of functions and are fundamental for brain homeostasis
(Nedergaard et al., 2003; Escartin et al., 2021). During early neurodevelopment, astrocytes have a trophic effect, facilitating the generation and migration of neuronal cells, facilitating synaptogenesis and the creation and maintenance of neuronal circuits (Ricci et al., 2009). One astrocyte can communicate with multiple neurons, with most of these structures being tripartite in nature; structural units formed of pre- and postsynaptic components of two neurons and an astrocyte (Araque et al., 1999; Halassa et al., 2007; Cavaccini et al., 2020). They can sense and respond to changes in the local microenvironment (e.g., local neurotransmitters) to control neuronal signaling (Wahis et al., 2021) and protect neurons from oxidative damage and neuronal injury. They are also important in energy metabolism (Brown and Ransom, 2007; Parra-Abarca et al., 2019), ionic homeostasis (Olsen et al., 2015), blood flow regulation (Howarth, 2014) and the formation of the blood brain barrier and can release gliotransmitters such as adenosine triphosphate (ATP), glutamate and D-serine (Parpura et al., 1994; Zhang et al., 2003; Volterra and Meldolesi, 2005; Hamilton and Attwell, 2010).

\section{Astrocytes and Neuroinflammation}

There is a growing evidence to suggest that astrocytes can modulate the immune system within the CNS and are important in regulating neuroinflammation (Rothhammer and Quintana, 2015). We have already discussed that neuroinflammatory 
processes can have both protective or detrimental effects on the developing brain. So too can astrocytic activation (Cekanaviciute and Buckwalter, 2016). Astrocyte activation can lead to the release of trophic factors such neurotrophin-3 (NT-3), glial cell line-derived neurotrophic factor (GDNF) and BDNF (Jurič et al., 2011; Thomsen et al., 2017). These growth-promoting molecules promote neuronal survival and GDNF has also been shown to inhibit microglial activation (Ossola et al., 2011; Rocha et al., 2012) resulting in a dampening down of neuroinflammation. Conversely, astrocytic activation can also lead to pro-inflammatory cytokine release, alongside increased concentrations of chemokines and reactive oxygen species and microglial activation (Sochocka et al., 2017) resulting in increased excitotoxicity, apoptosis and neurodegeneration. The mechanisms underlying the induction of a specific neuroinflammatory process remains poorly understood. Recent cutting-edge approaches have started to describe key target molecules important for the interactions between astrocytes and microglia in these neuroinflammatory processes (Clark et al., 2021). It is hoped that improved understanding of astrocytemicroglia cross-talk may then reveal new potential therapeutic targets for modulation that could be relevant in an array of neurodevelopmental disorders.

\section{Histamine's Regulation of Astrocytes}

The $\mathrm{H}_{1}, \mathrm{H}_{2}$, and $\mathrm{H}_{3}$ receptors are expressed on astrocytes (Jurič et al., 2016) (see Figure 2), though $\mathrm{H}_{3}$ receptor expression may be restricted to certain brain regions and may vary depending on the species that is studied (Karpati et al., 2018). Our current understanding of how astrocytes can respond to histaminergic activity in the brain originated over three decades ago (Hosli and Hosli, 1984; Hosli et al., 1984) and continue to be investigated. For example, Karpati et al. (2018) employed the human astrocytoma cell line $1321 \mathrm{~N} 1$ to better establish the underlying mechanism and found that histamine can interact with astrocytic histamine receptors resulting in glutamate release in an $\mathrm{H}_{1}$ receptor-dependent and concentration-dependent manner suggesting that histamine can form part of neuronastrocyte communications.

There is less data available if and how histaminergic activity might influence astrocytic immunomodulation. Some studies have shown that histamine can act synergistically with proinflammatory cytokines such as IL-1 (Lipnik-Stangelj and Carman-Krzan, 2006) and IL-6 (Lipnik-Štangelj and ČarmanKržan, 2005; Ales et al., 2008) to modulate astrocytic release of neurotrophins such as NGF. For example, Xu et al. (2018) investigated the role of histamine on astrocytic neuromodulation and neuroprotection. They found that histamine selectively upregulated the expression of $\mathrm{H}_{1}, \mathrm{H}_{2}$, and $\mathrm{H}_{3}$ receptors, stimulated the synthesis of astrocytic GDNF and inhibited the production of pro-inflammatory cytokines, TNF- $\alpha$ and IL- $1 \beta$ in a concentration-dependent manner. The increased production of neurotrophic factors likely highlights an important mechanistic role in CNS recovery from injury by promoting neuronal survival and synaptogenesis (Lipnik-Stangelj and Carman-Krzan, 2004; Jurič et al., 2011; Xu et al., 2018). We have already discussed that released GDNF can inhibit microglial activation in vivo and in vitro, thereby revealing a possible interaction between these glial cells in modifying (microglial-mediated) neuroinflammation (Rocha et al., 2012; Zhang et al., 2014). In addition see also recent findings suggestive of purinergic signaling from astrocytes to microglia upon histaminergic stimulation (Xia et al., 2021). Moreover, changes in astrocyteneuronal crosstalk have been implicated in the development of mental disorders, including depression, ASD and schizophrenia (Roman et al., 2020). However, to our knowledge, there are no studies that have investigated the specific role of histamine in directly modulating astrocytic behavior contributing to neurodevelopmental disorders.

\section{Mast Cells as a Non-neuronal Source of Histamine}

Mast cells are immune cells derived from hematopoietic precursors, originating within the bone marrow from CD34+/CD117+ pluripotent progenitors (Gilfillan et al., 2011). They then mature within the microenvironment of various tissues, including the vascular endothelium and the brain, where they participate in both innate and adaptive immune responses, even in the absence of antigen presentation (Dong et al., 2014b). Mast cells in general express $\mathrm{H}_{1}$ and $\mathrm{H}_{4}$ receptors, which have been implicated in the pathophysiology of peripheral type 1 hypersensitivity reactions and increased histamine and cytokine generation, respectively (Thangam et al., 2018) and guide chemotaxis (Hofstra et al., 2003; Halova et al., 2012). However, their expression in brain mast cells has yet to be confirmed. Mast cells are located in perivascular regions within close vicinity of neurons, especially in the hypothalamus, the pineal and pituitary glands (Theoharides, 2017), velum interpositum below the hippocampus (Panula et al., 2014), the meninges (Reuter et al., 2001; Galli et al., 2005a) and are able to cross the normal blood brain barrier (Silverman et al., 2000). The ability to traverse the blood brain barrier may be accentuated further by disease states affecting its integrity which can intimately be linked to mast cell activation and contribute to neuroinflammation and neurotoxicity (Theoharides et al., 2012), including during periods of neurodevelopment. Approximate mast cell numbers in the developing rodent brain have recently been described and are mainly localized to the pia mater and the thalamus. Within the pia mater, mast cells are most numerous during early development, with approximately 3,500 seen at birth, peaking at approximately 5,000 at postnatal day 11 . Numbers then decline to approximately 1,500 at P15, though the remaining mast cells become more concentrated in the pia that overlies the anterior thalamus. The total numbers of mast cell within the pia then reach adult levels of approximately 50 by P30. Within the thalamus, around 140 mast cells are seen at P8, which then steadily increases to reach adult values of 1,500 at P30 (Khalil et al., 2007; Panula et al., 2014).

Mast cells produce a range of mediators, some of which are preformed, whereas others are synthesized upon activation. These mediators include the biogenic amines histamine and serotonin, cytokines, specifically IL-1, IL-6, TNF- $\alpha$, interferon$\gamma(\mathrm{IFN}-\gamma)$, TGF- $\beta$, enzymes such as phospholipases, chymase, 
and mast cell proteases and tryptase, lipid mediators such as leukotrienes and prostaglandins, growth factors, nitric oxide, heparin, ATP and neuropeptides (Johnson and Krenger, 1992; Skaper et al., 2001; Dong et al., 2014b). Despite their small numbers they can affect numerous processes in the brain that have a potentially underestimated impact on neuroinflammation (see Figure 2). Preformed mediators may be released from secretory granules within seconds, followed by de novo formation of lipid mediators, cytokines and chemokines (Galli et al., 2005b; Nelissen et al., 2013; Silver and Curley, 2013). Mast cells are a heterogeneous cell type, with wide variation in mediator synthesis and release and a wide response in signaling pathways (Dong et al., 2014b) some of which seems to depend on histamine synthesis by mast cells itself (Ohtsu et al., 2001). Mast cells are an important source of histamine in the brain, with up to $50 \%$ of brain histamine levels in rodents attributable to the presence of mast cells (Yamatodani et al., 1982). This was established using high-performance liquid chromatography in mast cell deficient ( $\mathrm{Kit}^{W / W v}$ ) mice compared to controls at 24 months after birth (Yamatodani et al., 1982). Such mice have reduced $c$-kit tyrosine kinase-dependent signaling, leading to impaired mast cell development and survival (Kitamura et al., 1978; Grimbaldeston et al., 2005). These mice are profoundly deficient in mast cells, with adult mice containing no detectable mast cells across numerous anatomical sites by $6-8$ weeks of age (Kitamura et al., 1978).

\section{Mast Cell Interactions With Microglia}

Mast cells are a non-neuronal source of histamine that can be released upon degranulation. We have already discussed the role of histamine-mediated microglial activation and the release of the pro-inflammatory cytokines IL- 6 and TNF- $\alpha$ in vitro via $\mathrm{H}_{1}$ and $\mathrm{H}_{4}$ receptors and MAPK and PI3K/AKT pathway activation (Dong et al., 2014a). Other implicated pathways include the complement 5a receptor and chemokine receptor 4/12 (CXCr4 and CXCL12) (Dong et al., 2014a) and the chemoattractant, C-C Motif Chemokine Ligand 5 (CCL5) (Hendriksen et al., 2017). We can therefore see an array of in vitro evidence for bidirectional interactions between mast cells and microglia in regulating neuroinflammation some of which are highlighted below (see also Figure 2).Dong et al. (2017) provided the first data on in vivo mast cell-microglial interactions, demonstrating that activation of brain mast cells by injecting the mast cell degranulator, C48/80 directly into the hypothalamus triggered microglial activation and the release of the pro-inflammatory cytokines, IL- 6 and TNF- $\alpha$. In turn, this was opposed by mast cell stabilization using sodium cromoglycate. Indeed, this resulted in a decrease in pro-inflammatory cytokines and reduced expression of the innate immune protein, toll-like receptor 4 (TLR4), and $\mathrm{H}_{1}$ and $\mathrm{H}_{4}$ receptors on the microglia. In turn, there was no effect on microglial activation in mast-cell deficient $\mathrm{Kit}^{W-s h / W /-s h}$ mice. Similar to the $\mathrm{Kit}^{W / W v}$ mice discussed previously, these mice have reduced $c$-kit tyrosine kinase-dependent signaling, leading to impaired mast cell development and survival (Kitamura et al., 1978; Grimbaldeston et al., 2005). However, the specific mutation used is thought to lead to fewer developmental abnormalities that the Kit ${ }^{W / W v}$ model while still retaining the desired mast cell deficiency (Yamazaki et al., 1994; Grimbaldeston et al., 2005). The findings by Dong et al. (2017) are important not only in confirming an interaction between mast cells and microglia in vivo, but also in highlighting the importance of mast cell degranulation for this interaction. Given that mast cell activation may be the first responder to injury (Jin et al., 2009b), and not the microglia, inhibition of mast cell activation may inhibit the pro-inflammatory cascade and therefore protect against neuroinflammation. What remains poorly understood is the contribution and role of histamine, if any, in this interaction. However, as the altered microglial expression of the $\mathrm{H}_{1}$ and $\mathrm{H}_{4}$ receptors depends on the activation state of mast cells (Dong et al., 2017) this may be suggestive that mast cell sources of histamine, not just neuronal sources, are crucial in the initiation of neuroinflammation.

\section{Mast Cell Interactions With Astrocytes and Neurons}

As well as mast cell-microglial interactions, there is some emerging evidence that mast cells may have direct interactions with CNS neurons and astrocytes as outlined below. Indeed, mast cells tend to co-localize with neurons (Skaper et al., 2012; Silver and Curley, 2013) or even to strongly adhere to neurons (Hagiyama et al., 2011). Neuronal release of neuropeptides such as NGF, neurotensin and substance $P$ have been shown to bind directly bind to mast cells, altering their activation state (Kulka et al., 2008). Conversely, mast cells may also communicate with neurons via transgranulation, whereby mast cell granules can be inserted into adjacent neurons that alters neuronal responsiveness to its microenvironment (Wilhelm et al., 2005) (see Figure 3). Kempuraj et al. (2019) investigated such interactions in a mouse model of Parkinson's disease. They found that mouse mast cell protease- 6 and 7 induced the release of interleukin 33 (IL-33) from astrocytes and a mixed culture of glia and neuronal cells. This suggested that mast cells might interact with astrocytes and neurons to accelerate neuroinflammation and neurodegeneration. Kim et al. (2010) investigated the signaling pathways of activated mast cells and their interaction with astrocytes in experimental allergic encephalomyelitis. This was used as a model for the chronic demyelinating disease, multiple sclerosis. Co-culturing of mast cells with astrocytes led to increased release of histamine, leukotrienes and pro-inflammatory cytokines. It does so via enhanced expression of CD40L on mast cells, which is the natural ligand for CD40 expressed on astrocytes. This CD40-CD40L may therefore be important in chronic disease associated with neuroinflammation. Lenz et al. (2018) investigated the role of mast cells, and specifically histamine released from mast cell degranulation on neuronal development in the preoptic area of the hypothalamus. This is a crucial brain region in determining sexual behavior. Mast cell activation with the estrogen steroid hormone, estradiol, was found to stimulate microglial activation, subsequent prostaglandin release which was associated with increased dendritic spine density and the dendritic spine protein, spinophilin, as well as more masculinized sexual behavior. A small number of mast cells therefore had a profound effect 
on overall brain development and resultant behavior. To our knowledge, there are no further studies that have investigated the effect of mast cell activation and non-neuronal histamine directly on the CNS in vivo. However, bi-directional communication was recently demonstrated between mast cells and neurons in the skin (Zhang et al., 2021), which may demonstrate a role in the mediation of epidermal and dermal inflammation. Mast cell sources of histamine have also been implicated in the pathophysiology of neuropathic pain (Rosa and Fantozzi, 2013).

\section{Mast Cells and Neurodevelopmental Disorders}

Given their numerous cellular interactions and their role in neuroinflammation, it has been postulated that brain mast cells may be implicated in NDDs such as ASD (Theoharides et al., 2013) and ADHD (Song et al., 2020) but further roles in the etiology of NDDs remain unclear. The association with ASD is suggested by findings of mast cell related markers such as elevated serum neurotensin (Carraway et al., 1982; Alysandratos et al., 2012; Tsilioni et al., 2014), proinflammatory cytokines (Li et al., 2009) and the chemoattractant, monocyte chemoattractant protein-1 (MCP-1) (Vargas et al., 2005) in brain parenchyma and cerebrospinal fluid in patients with ASD. Secondly, ADHD has been commonly seen alongside allergic, inflammatory and autoimmune diseases (Song et al., 2020) and children with atopic eczema may be more susceptible to developing ADHD (Genuneit et al., 2014). This, along with the previously discussed associations between ADHD and neuroinflammation, has led to interest in mast cells as an important mediator of this (Song et al., 2020). However, to our knowledge, there are no studies that have investigated the potential role, if any, of mast cells in ADHD specifically.

\section{HISTAMINE AS A THERAPEUTIC TARGET IN NEURODEVELOPMENTAL DISORDERS}

So far, we have discussed that histamine is not only a neuromodulator but can be a modulator of neuroinflammation and can be part of the complex interaction between mast cells, microglia and astrocytes. Interactions between these various cells are well suited to modulate many aspects of brain development. As such histamine may be a potential therapeutic target for pharmacological manipulation to either prevent or treat the signs and symptoms of a variety of neurodevelopmental disorders (NDDs). Here we will discuss a range of compounds that have been developed to act at histamine receptors and are being investigated in the management of NDDs (see Table 3). Although often assumed to be acting mainly at neurons it remains possible that non-neuronal cells are also involved.

\section{$\mathrm{H}_{\mathbf{1}}$ Receptor Antagonists}

The only study so far to use an $\mathrm{H}_{1}$ receptor antagonist in the treatment of a NDD is a case report by Verhoeven et al. (2020). They describe a male with a rare missense mutation in the HNMT gene located in chromosome 2 q22.1 that resulted in reduced histamine metabolism within the CNS. This was associated with a severe intellectual disability. The combination of a low histidine diet and the $\mathrm{H}_{1}$ receptor antagonist, hydroxyzine, led to an improvement in sleep, speech development and reduction in aggression. While $\mathrm{H}_{1}$ receptor antagonists such as promethazine may also be used in the symptomatic treatment of insomnia, there is no evidence of such agents having a disease modifying effect in NDDs.

\section{$\mathrm{H}_{2}$ Receptor Antagonists}

The $\mathrm{H}_{2}$ receptor antagonist, famotidine, has been trialed for treatment of social deficits that can be a clinical feature of both ASD and schizophrenia. The rationale was based on a case report by Kaminsky et al. (1990) who described incidental improvements in social deficits in an adult with schizophrenia when treated with famotidine for peptic ulcer disease. Subsequent studies then observed benefits when used as an adjunct treatment in schizophrenia with doses up to $100 \mathrm{mg}$ per day (Deutsch et al., 1993; Oyewumi et al., 1994; Rosse et al., 1995; Linday et al., 2001). However, this improvement in social function has not been consistently replicated in randomized trials. Famotidine did not benefit those with ASD and marked stereotypies (Linday et al., 2001). The authors did not provide an explanation for this, but did discuss the difficulties with subtyping disorders such as ASDs based on behavior alone. In addition, while scores on the Clinical Global Impression (Deutsch et al., 1993; Meskanen et al., 2013), Total Brief Psychiatric Rating (Deutsch et al., 1993) and Positive and Negative Syndrome (Meskanen et al., 2013) scales improved in those with schizophrenia treated with adjunct famotidine, no improvements were seen in scales for negative symptoms (Deutsch et al., 1993; Meskanen et al., 2013). Given the $\mathrm{H}_{2}$ receptor inverse agonism noted with the antipsychotic, clozapine (Humbert-Claude et al., 2012), the authors speculated that famotidine's $\mathrm{H}_{2}$ receptor antagonism might, at least in part, have an antipsychotic effect (Meskanen et al., 2013). It may also be that famotidine improves sociability in people with schizophrenia by alleviating anxiety associated with positive symptoms rather than a disease modulating effect on negative symptoms. However, the potential mechanism(s) for this have not been established.

\section{$\mathrm{H}_{3}$ Receptor Antagonists}

The $\mathrm{H}_{3}$ receptor antagonists/inverse agonists are the most widely studied group of agents. Pitolisant is the only such agent licensed for use in adults and approved for the treatment of excessive daytime sleepiness for those with narcolepsy with or without cataplexy. It has high affinity and selectivity for the $\mathrm{H}_{3}$ receptor. Specifically, the administration of a dose of $40 \mathrm{mg}$ of pitolisant has been shown to lead to $\mathrm{H}_{3}$ receptor occupancy of $84 \pm 7 \%$ at the time of peak plasma concentration (Rusjan et al., 2020). Pitolisant induces central histaminergic and noradrenergic transmission in animal models that increase wakefulness and decrease REM sleep. Several studies have demonstrated its safety and tolerability (Lin et al., 2008; Inocente et al., 2012; Harwell and Fasinu, 2020) before the HARMONY I (Dauvilliers et al., 2013), 
TABLE 3 | Summary of preclinical and clinical studies of histamine receptor modulators in neuropsychiatric disease.

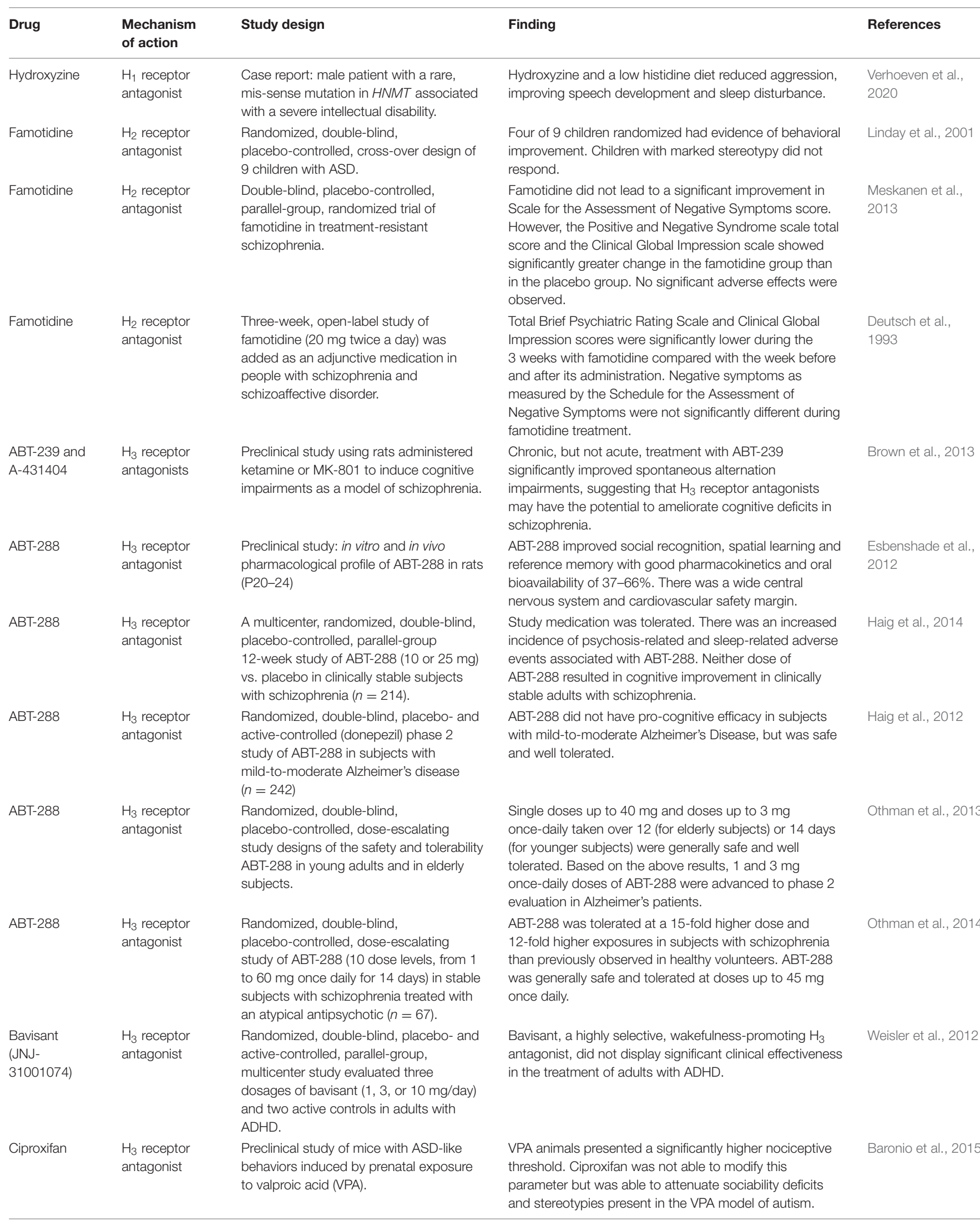


TABLE 3 | Continued.

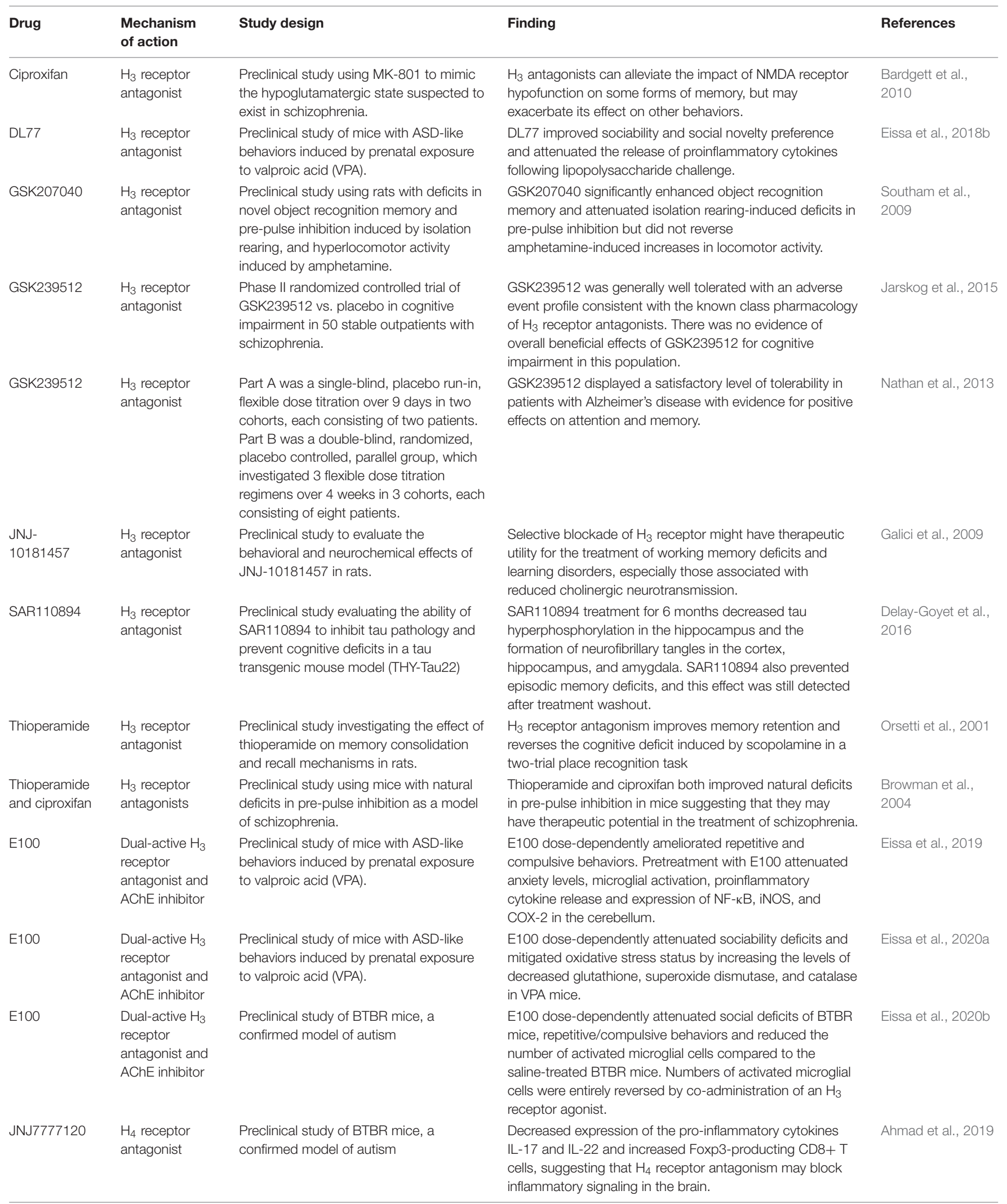

AChE, acetylcholinesterase; ASD, autism spectrum disorder; BTBR, BTBR $T^{+} / \mathrm{tp} \mathrm{3}^{\mathrm{tf}} / \mathrm{J}$ mouse; COX-2, cyclo-oxygenase-2; HNMT, histamine N-methyltransferase; $\mathrm{H}_{1}$, histamine 1; $\mathrm{H}_{2}$, histamine 2; $\mathrm{H}_{3}$, histamine 3; $\mathrm{H}_{4}$, histamine 4; IL-17, interleukin-17; IL-22, interleukin-22; iNOS, inducible nitric oxide synthase; NF-кB, nuclear factor-кB; VPA, valproic acid. 
HARMONY III (Dauvilliers et al., 2019), and HarmonyCTP trials (Szakacs et al., 2017) demonstrated its efficacy. It has also been shown to reduce excessive daytime sleepiness in obstructive sleep apnea (Dauvilliers et al., 2020), though is not clinically recommended as an alternative to existing treatments that target the underlying cause and multisystem consequences of obstructive sleep apnea such as continuous positive airway pressure (Trotti, 2020). Moreover, Pitolisant has shown procognitive efficacy in children with Prader Willi syndrome (PWS). Approximately $65 \%$ of those with PWS will experience sleep disturbance such as sleep apnea or daytime sleepiness (Pullen et al., 2019). It was this that prompted interest into the potential role of pitolisant given its approval in treating narcolepsy with or without cataplexy. However, for those with PWS, the benefits experienced appeared to extend beyond that of alleviating excessive daytime sleepiness (Pullen et al., 2019). From this, there is now increasing interest in epigenetic approaches that combine $\mathrm{H}_{3}$ receptor antagonism/inverse agonism with inhibitors of histone $\mathrm{H} 3$ lysine9 (H3K9) methyltransferase G9a with the aim of restoring expression of the candidate PWS genes on the maternally inherited chromosome (Reiner et al., 2020). It is hoped that such approaches may help improve the profiles of further $\mathrm{H}_{3}$ receptor antagonist/inverse agonists where thus far, there has been limited reproducibility of findings from preclinical to clinical studies. While animal models have shown a potential role for pitolisant in other conditions such as epilepsy (Sadek et al., 2014), this has so far not translated to benefit in human studies (Kasteleijn-Nolst Trenite et al., 2013).

Altered sleep-wake cycles are common in those with ASD, including circadian rhythm disorders, dyssomnias and parasomnias (Souders et al., 2017; Hohn et al., 2019; Ballester et al., 2020; Jovevska et al., 2020). To our knowledge, there have not been studies into the use of pitolisant as a wake promoting agent specifically in those with NDDs. However, other $\mathrm{H}_{3}$ receptor antagonists/inverse agonists are in development for other indications relevant to those with NDDs. Most these have focused on the modulating restricted and repetitive behaviors or aggression or at improving cognition and sociability in animal models (Orsetti et al., 2001; Galici et al., 2009; Southam et al., 2009; Esbenshade et al., 2012; Brown et al., 2013; Baronio et al., 2015; Eissa et al., 2018a,b, 2020b). For example, a clinical trial with the $\mathrm{H}_{3}$ receptor antagonist, AZD5213, for people with TS showed a 2-3 point reduction in Total Tic Severity Score Compared to placebo (Clinical Trials.Gov, 2016). However, one study that investigated the use of three doses of the $\mathrm{H}_{3}$ receptor antagonist, bavisant, in adults with ADHD did not find any clinical benefit (Weisler et al., 2012). The lower doses of 1 and $3 \mathrm{mg} /$ day were well tolerated, but $10 \mathrm{mg} /$ day was associated with higher rates of discontinuation due to adverse effects (particularly sleep-related adverse effects). In comparison, methylphenidate $54 \mathrm{mg} /$ day and atomoxetine $80 \mathrm{~m} /$ day were more efficacious than placebo. The authors concluded that direct modulation of dopamine and noradrenaline transmission may be better than histamine modulation in the alleviation of ADHD symptoms. Furthermore, preclinical studies demonstrated procognitive effects of the $\mathrm{H}_{3}$ receptor antagonist, ABT-288 (Esbenshade et al., 2012). A phase 1 study of adjunct treatment using ABT-288 was tolerated at a dose 15 times higher in humans with schizophrenia than had previously been seen in healthy volunteers (Othman et al., 2014). However, a 12-week phase 2, multicenter, randomized controlled trial of ABT-288 (10 mg, $25 \mathrm{mg}$ or placebo) did not demonstrate a pro-cognitive effect in people with schizophrenia (Haig et al., 2014). Overall, while these agents appear well tolerated in human studies (Dauvilliers et al., 2013; Othman et al., 2013, 2014; Szakacs et al., 2017; Dauvilliers et al., 2019, 2020), there is limited consistent data to suggest they are efficacious in treating symptoms seen in NDDs (Haig et al., 2012, 2014; Weisler et al., 2012; Jarskog et al., 2015). Indeed, the contrast between positive preclinical findings with negative clinical trials may also reflect the challenges in finding translatable animal models for neuropsychiatric disorders (Howe et al., 2018).

\section{$\mathrm{H}_{4}$ Receptor Antagonists}

The expression of the $\mathrm{H}_{4}$ receptor on microglia and mast cells led to interest in the use of $\mathrm{H}_{4}$ receptor antagonists in reducing neuroinflammation in the treatment of NDDs such as ASD. For example, Ahmad et al. (2019) used one such experimental $\mathrm{H}_{4}$ receptor antagonist, which led to decreased expression of pro-inflammatory cytokines. However, this study did not ascertain if this effect was associated with an amelioration of symptoms associated with ASD. The selective $\mathrm{H}_{3}$ receptor antagonist, clobenpropit, has also shown off-target $\mathrm{H}_{4}$ receptor partial agonism (Patnaik et al., 2018). Like the $\mathrm{H}_{3}$ receptor inverse agonist, BF 2649, this agent led to a reduction in beta amyloid deposits and gliosis in a rat model of Alzheimer's disease (Patnaik et al., 2018). It is unclear if and to what extent the $\mathrm{H}_{4}$ receptor affinity may contribute to this potential neuroprotective effect. To our knowledge, there are no $\mathrm{H}_{4}$ receptor modulators that have been tested in clinical trials.

It is important to note that those with NDDs tend to be under-represented in clinical trials. The reasons for this may be due to concerns over the high frequency of comorbidity that may limit the internal validity of any findings, concerns over capacity to consent, particularly those with a comorbid intellectual disability, and the resources to adapt written information and data collection tools to promote participation in those with are non-verbal. While existing trials are focusing on repurposed agents such as the diuretic bumetanide, the vasopressin 1a receptor agonist, balovaptan and the $\mathrm{GABA}_{B}$ receptor agonist, baclofen, modulation of histamine receptors may be an additional viable target in helping to ameliorate difficulties associated with NDDs.

\section{CONCLUSION}

In this Review, we have highlighted the importance of the biogenic amine, histamine, in modulating the development of key neuronal circuits that are implicated in neurodevelopmental 
disorders, such as ASD and TS amongst others, as well as regulating inflammatory processes in the brain. Most studies have focused on neuronal sources of histamine but what remains unclear is to what extent other sources of histamine, for example from mast cells, participate in these processes and allow for interactions between neuronal and non-neuronal cells. While existing studies have been predominantly in vitro, there is some, albeit limited, in vivo data that indicates that mast cell degranulation and the release of preformed mediators, such as histamine, can influence microglial-mediated neuroinflammation in a bidirectional manner. There is also evidence of direct interactions between mast cells and astrocytes and neurons, which may be through the release of nonneuronal histamine. However, to our knowledge, there are no studies that investigate the specific role of mast cell sources of histamine on modulating both neuroinflammation and its subsequent impact on synaptic development in key neural circuits that underpin NDDs in vivo. This therefore represents an important area of future research as early modulation of mast cell function may provide a novel therapeutic target for NDDs including TS, ASD, ADHD and schizophrenia. In addition, the potential therapeutic role of histamine receptor modulators and the well-tolerated group of $\mathrm{H}_{3}$ receptor

\section{REFERENCES}

Abelson, J. F., Kwan, K. Y., O'roak, B. J., Baek, D. Y., Stillman, A. A., Morgan, T. M., et al. (2005). Sequence variants in SLITRK1 are associated with Tourette's syndrome. Science 310, 317-320. doi: 10.1126/science.111 6502

Ahmad, S. F., Nadeem, A., Ansari, M. A., Bakheet, S. A., Al-Mazroua, H. A., Khan, M. R., et al. (2019). The histamine-4 receptor antagonist JNJ7777120 prevents immune abnormalities by inhibiting RORgammat/T-bet transcription factor signaling pathways in BTBR T(+) Itpr3(tf)/J mice exposed to gamma rays. Mol. Immunol. 114, 561-570. doi: 10.1016/j.molimm.2019.09.007

Albin, R. L., and Mink, J. W. (2006). Recent advances in Tourette syndrome research. Trends Neurosci. 29, 175-182. doi: 10.1016/j.tins.2006.01.001

Ales, K., Wraber, B., and Lipnik-Stangelj, M. (2008). The synergistic effect of histamine and IL-6 on NGF secretion from cultured astrocytes is evoked by histamine stimulation of IL-6 secretion via H1-receptor-PKC-MAPK signalling pathway. Inflamm. Res. 57, S33-S34.

Alexander, J., Potamianou, H., Xing, J., Deng, L., Karagiannidis, I., Tsetsos, F., et al. (2016). Targeted Re-Sequencing approach of candidate genes implicates rare potentially functional variants in tourette syndrome etiology. Front. Neurosci. 10:428. doi: 10.3389/fnins.2016.00428

Allswede, D. M., and Cannon, T. D. (2018). Prenatal inflammation and risk for schizophrenia: A role for immune proteins in neurodevelopment. Dev. Psychopathol. 30, 1157-1178. doi: 10.1017/s0954579418000317

Aloisi, F. (2001). Immune function of microglia. Glia 36, 165-179. doi: 10.1002/ glia.1106

Alysandratos, K.-D., Asadi, S., Angelidou, A., Zhang, B., Sismanopoulos, N., Yang, H., et al. (2012). Neurotensin and CRH interactions augment human mast cell activation. PloS One 7:e48934. doi: 10.1371/journal.pone.004 8934

Amphoux, A., Vialou, V., Drescher, E., Bruss, M., Mannoury La Cour, C., Rochat, C., et al. (2006). Differential pharmacological in vitro properties of organic cation transporters and regional distribution in rat brain. Neuropharmacology 50, 941-952. doi: 10.1016/j.neuropharm.2006.01.005

Anand, D., Colpo, G. D., Zeni, G., Zeni, C. P., and Teixeira, A. L. (2017). Attentiondeficit/hyperactivity disorder and inflammation: what does current knowledge tell us? A systematic review. Front. Psychiatry 8:228. doi: 10.3389/fpsyt.2017. 00228 antagonists/inverse agonists may represent a promising area in the management of NDDs.

\section{AUTHOR CONTRIBUTIONS}

EC wrote the first draft of the manuscript. EC and TE wrote sections of the manuscript. Both authors contributed to manuscript revision, read, and approved the submitted version.

\section{FUNDING}

This work had support from an MRC Career Development Award (MR/M009599/1) and MSD Pump Priming Award (8473) to TE and an ACF research funding and Oxfordshire Health Services Research Committee grant (2020/1363) to EC.

\section{ACKNOWLEDGMENTS}

We thank Ricardo Marquez-Gomez for helpful suggestions and comments.

Araque, A., Parpura, V., Sanzgiri, R. P., and Haydon, P. G. (1999). Tripartite synapses: glia, the unacknowledged partner. Trends Neurosci. 22, 208-215. doi: 10.1016/s0166-2236(98)01349-6

Arrang, J. M., Garbarg, M., Lancelot, J. C., Lecomte, J. M., Pollard, H., Robba, M., et al. (1987). Highly potent and selective ligands for histamine H3-receptors. Nature 327, 117-123. doi: 10.1038/327117a0

Arrang, J. M., Garbarg, M., and Schwartz, J. C. (1983). Auto-inhibition of brain histamine release mediated by a novel class (H3) of histamine receptor. Nature 302, 832-837. doi: 10.1038/302832a0

Arrang, J. M., Morisset, S., and Gbahou, F. (2007). Constitutive activity of the histamine H3 receptor. Trends Pharmacol. Sci. 28, 350-357. doi: 10.1016/j.tips. 2007.05.002

Auvinen, S., and Panula, P. (1988). Development of histamine-immunoreactive neurons in the rat brain. J. Comp. Neurol. 276, 289-303. doi: 10.1002/cne. 902760211

Baird, G., Simonoff, E., Pickles, A., Chandler, S., Loucas, T., Meldrum, D., et al. (2006). Prevalence of disorders of the autism spectrum in a population cohort of children in south thames: the Special Needs and Autism Project (SNAP). Lancet 368, 210-215. doi: 10.1016/s0140-6736(06)69041-7

Baldan, L. C., Williams, K. A., Gallezot, J. D., Pogorelov, V., Rapanelli, M., Crowley, M., et al. (2014). Histidine decarboxylase deficiency causes tourette syndrome: parallel findings in humans and mice. Neuron 81, 77-90. doi: 10.1016/j.neuron. 2013.10.052

Ballester, P., Richdale, A. L., Baker, E. K., and Peiro, A. M. (2020). Sleep in autism: A biomolecular approach to aetiology and treatment. Sleep Med. Rev. 54:101357. doi: 10.1016/j.smrv.2020.101357

Bar, E., and Barak, B. (2019). Microglia roles in synaptic plasticity and myelination in homeostatic conditions and neurodevelopmental disorders. Glia 67, 21252141. doi: $10.1002 /$ glia.23637

Bardgett, M. E., Points, M., Kleier, J., Blankenship, M., and Griffith, M. S. (2010). The H3 antagonist, ciproxifan, alleviates the memory impairment but enhances the motor effects of MK-801 (dizocilpine) in rats. Neuropharmacology 59, 492-502. doi: 10.1016/j.neuropharm.2010. 07.004

Barnes, W. G., and Hough, L. B. (2002). Membrane-bound histamine $\mathrm{N}$-methyltransferase in mouse brain: possible role in the synaptic inactivation of neuronal histamine. J. Neurochem. 82, 1262-1271. doi: 10.1046/j.1471-4159. 2002.01063.x 
Baronio, D., Castro, K., Gonchoroski, T., De Melo, G. M., Nunes, G. D. F., BambiniJunior, V., et al. (2015). Effects of an H3R antagonist on the animal model of autism induced by prenatal exposure to valproic acid. PLoS One 10:e0116363. doi: 10.1371/journal.pone.0116363

Bennet, L., Dhillon, S., Lear, C. A., Van Den Heuij, L., King, V., Dean, J. M., et al. (2018). Chronic inflammation and impaired development of the preterm brain. J. Reprod. Immunol. 125, 45-55. doi: 10.1016/j.jri.2017.11.003

Bernardino, L., Eiriz, M. F., Santos, T., Xapelli, S., Grade, S., Rosa, A. I., et al. (2012). Histamine stimulates neurogenesis in the rodent subventricular zone. Stem Cells 30, 773-784. doi: 10.1002/stem.1042

Bernstein, H. G., Piontkewitz, Y., and Keilhoff, G. (2016). Commentary: Maternal immune activation evoked by polyinosinic: polycytidylic acid does not evoke microglial cell activation in the embryo. Front. Cell Neurosci. 10:41. doi: 10. 3389/fncel.2016.00041

Biber, K., Neumann, H., Inoue, K., and Boddeke, H. W. (2007). Neuronal 'On' and 'Off' signals control microglia. Trends Neurosci. 30, 596-602. doi: 10.1016/j. tins.2007.08.007

Blandina, P., Munari, L., Provensi, G., and Passani, M. B. (2012). Histamine neurons in the tuberomamillary nucleus: a whole center or distinct subpopulations? Front. Syst. Neurosci. 6:33. doi: 10.3389/fnsys.2012.00033

Bolam, J. P., and Ellender, T. J. (2016). Histamine and the striatum. Neuropharmacology 106, 74-84. doi: 10.1016/j.neuropharm.2015.08.013

Borycz, J., Borycz, J. A., Loubani, M., and Meinertzhagen, I. A. (2002). tan and ebony genes regulate a novel pathway for transmitter metabolism at fly photoreceptor terminals. J. Neurosci. 22, 10549-10557. doi: 10.1523/jneurosci. 22-24-10549.2002

Brown, A. M., and Ransom, B. R. (2007). Astrocyte glycogen and brain energy metabolism. Glia 55, 1263-1271. doi: 10.1002/glia.20557

Brown, J. W., Whitehead, C. A., Basso, A. M., Rueter, L. E., and Zhang, M. (2013). Preclinical evaluation of non-imidazole histamine $\mathrm{H} 3$ receptor antagonists in comparison to atypical antipsychotics for the treatment of cognitive deficits associated with schizophrenia. Int. J. Neuropsychopharmacol. 16, 889-904. doi: $10.1017 / \mathrm{s} 1461145712000739$

Brown, R. E., Fedorov, N. B., Haas, H. L., and Reymann, K. G. (1995). Histaminergic modulation of synaptic plasticity in area CA1 of rat hippocampal slices. Neuropharmacology 34, 181-190. doi: 10.1016/0028-3908(94)00138-i

Brown, R. E., and Haas, H. L. (1999). On the mechanism of histaminergic inhibition of glutamate release in the rat dentate gyrus. J. Physiol. 515, 777-786. doi: 10.1111/j.1469-7793.1999.777ab.x

Browman, K. E., Komater, V. A., Curzon, P., Rueter, L. E., Hancock, A. A., Decker, M. W., et al. (2004). Enhancement of prepulse inhibition of startle in mice by the $\mathrm{H} 3$ receptor antagonists thioperamide and ciproxifan. Behav. Brain Res. 153, 69-76. doi: 10.1016/j.bbr.2003.11.001

Bowsher, R. R., Verburg, K. M., and Henry, D. P. (1983). Rat histamine N-methyltransferase. Quantification, tissue distribution, purification, and immunologic properties. J. Biol. Chem. 258, 12215-12220. doi: 10.1016/s00219258(17)44159-7

Brugha, T. S., Mcmanus, S., Bankart, J., Scott, F., Purdon, S., Smith, J., et al. (2011). Epidemiology of autism spectrum disorders in adults in the community in England. Arch. Gen. Psychiatry 68, 459-465.

Buehler, M. R. (2011). A proposed mechanism for autism: an aberrant neuroimmune response manifested as a psychiatric disorder. Med. Hypotheses 76, 863-870. doi: 10.1016/j.mehy.2011.02.038

Calabresi, P., Maj, R., Pisani, A., Mercuri, N. B., and Bernardi, G. (1992a). Longterm synaptic depression in the striatum: physiological and pharmacological characterization. J. Neurosci. 12, 4224-4233. doi: 10.1523/jneurosci.12-1104224.1992

Calabresi, P., Pisani, A., Mercuri, N. B., and Bernardi, G. (1992b). Long-term potentiation in the striatum is unmasked by removing the voltage-dependent magnesium block of NMDA receptor channels. Eur. J. Neurosci. 4, 929-935. doi: 10.1111/j.1460-9568.1992.tb00119.x

Carraway, R., Cochrane, D. E., Lansman, J. B., Leeman, S. E., Paterson, B. M., and Welch, H. J. (1982). Neurotensin stimulates exocytotic histamine secretion from rat mast cells and elevates plasma histamine levels. J. Physiol. 323, 403-414. doi: 10.1113/jphysiol.1982.sp014080

Cavaccini, A., Durkee, C., Kofuji, P., Tonini, R., and Araque, A. (2020). Astrocyte signaling gates long-term depression at corticostriatal synapses of the direct pathway. J. Neurosci. 40:5757. doi: 10.1523/jneurosci.2369-19.2020
Cekanaviciute, E., and Buckwalter, M. S. (2016). Astrocytes: integrative regulators of neuroinflammation in stroke and other neurological diseases. Neurotherapeutics 13, 685-701. doi: 10.1007/s13311-016-0477-8

Chao, T.-K., Hu, J., and Pringsheim, T. (2014). Prenatal risk factors for Tourette Syndrome: a systematic review. BMC Pregnancy Childbirth 14:53. doi: 10.1186/ 1471-2393-14-53

Chaturvedi, R., Reddig, K., and Li, H. S. (2014). Long-distance mechanism of neurotransmitter recycling mediated by glial network facilitates visual function in Drosophila. Proc. Natl. Acad. Sci. U S A. 111, 2812-2817. doi: 10.1073/pnas. 1323714111

Chen, S. K., Tvrdik, P., Peden, E., Cho, S., Wu, S., Spangrude, G., et al. (2010). Hematopoietic origin of pathological grooming in Hoxb8 mutant mice. Cell 141, 775-785. doi: 10.1016/j.cell.2010.03.055

Chen, Y. N., Sha, H. H., Wang, Y. W., Zhou, Q., Bhuiyan, P., Li, N. N., et al. (2020). Histamine 2/3 receptor agonists alleviate perioperative neurocognitive disorders by inhibiting microglia activation through the PI3K/AKT/FoxO1 pathway in aged rats. J. Neuroinflamm. 17:217.

Cheng, L., Xu, C., Wang, L., An, D., Jiang, L., Zheng, Y., et al. (2021). Histamine $\mathrm{H} 1$ receptor deletion in cholinergic neurons induces sensorimotor gating ability deficit and social impairments in mice. Nat. Commun. 12:1142.

Chepkova, A., Yanovsky, E., Parmentier, R., Ohtsu, H., Haas, H. L., Lin, J.-S., et al. (2012). Histamine receptor expression, hippocampal plasticity and ammonia in histidine decarboxylase knockout mice. Cell. Mol. Neurobiol. 32, 17-25. doi: 10.1007/s10571-011-9730-1

Chini, M., Popplau, J. A., Lindemann, C., Carol-Perdiguer, L., Hnida, M., Oberlander, V., et al. (2020). Resolving and rescuing developmental miswiring in a mouse model of cognitive impairment. Neuron 105, 60-74. doi: 10.1016/j. neuron.2019.09.042

Clancy, B., Darlington, R. B., and Finlay, B. L. (2001). Translating developmental time across mammalian species. Neuroscience 105, 7-17. doi: 10.1016/s03064522(01)00171-3

Clark, I. C., Gutierrez-Vazquez, C., Wheeler, M. A., Li, Z., Rothhammer, V., Linnerbauer, M., et al. (2021). Barcoded viral tracing of single-cell interactions in central nervous system inflammation. Science 372:eabf1230. doi: 10.1126/ science.abf 1230

Clarke, R. A., Lee, S., and Eapen, V. (2012). Pathogenetic model for Tourette syndrome delineates overlap with related neurodevelopmental disorders including Autism. Transl. Psychiatry 2:e158. doi: 10.1038/tp.2012.75

Cleaton, M. A. M., and Kirby, A. (2018). Why do we find it so hard to calculate the burden of neurodevelopmental disorders? J. Childhood Dev. Disord. 4, 1-20.

Clinical Trials.Gov. (2016). Safety, Tolerability, Pharmacokinetic, and Efficacy Study of AZD5213 in Adolescents With Tourette's Disorder [Online]. Available Online at: https://www.clinicaltrials.gov/ct2/show/results/NCT01904773 [Accessed 11th March 2021]

Connelly, W. M., Shenton, F. C., Lethbridge, N., Leurs, R., Waldvogel, H. J., Faull, R. L., et al. (2009). The histamine H4 receptor is functionally expressed on neurons in the mammalian CNS. Br. J. Pharmacol. 157, 55-63. doi: 10.1111/ j.1476-5381.2009.00227.x

Coomey, R., Stowell, R., Majewska, A., and Tropea, D. (2020). The role of microglia in neurodevelopmental disorders and their therapeutics. Curr. Top Med. Chem. 20, 272-276. doi: 10.2174/1568026620666200221172619

Coutinho, E., Jacobson, L., Pedersen, M. G., Benros, M. E., Norgaard-Pedersen, B., Mortensen, P. B., et al. (2017a). CASPR2 autoantibodies are raised during pregnancy in mothers of children with mental retardation and disorders of psychological development but not autism. J. Neurol. Neurosurg. Psychiatry 88, 718-721. doi: 10.1136/jnnp-2016-315251

Coutinho, E., Menassa, D., Jacobson, L., West, S., Domingos, J., Moloney, T., et al. (2017b). Maternal CASPR2 antibodies and neurodevelopmental disorders in the offspring: epidemiological findings and an animal model. Lancet 389:S18.

Coutinho, E., Menassa, D. A., Jacobson, L., West, S. J., Domingos, J., Moloney, T. C., et al. (2017c). Persistent microglial activation and synaptic loss with behavioral abnormalities in mouse offspring exposed to CASPR2-antibodies in utero. Acta Neuropathol. 134, 567-583. doi: 10.1007/s00401-017-1751-5

Cowan, M., and Petri, W. A. Jr. (2018). Microglia: immune regulators of neurodevelopment. Front. Immunol. 9:2576. doi: 10.3389/fimmu.2018.02576

Dai, H., Kaneko, K., Kato, H., Fujii, S., Jing, Y., Xu, A., et al. (2007). Selective cognitive dysfunction in mice lacking histamine $\mathrm{H} 1$ and $\mathrm{H} 2$ receptors. Neurosci. Res. 57, 306-313. doi: 10.1016/j.neures.2006.10.020 
Dalton, P., Deacon, R., Blamire, A., Pike, M., Mckinlay, I., Stein, J., et al. (2003). Maternal neuronal antibodies associated with autism and a language disorder. Ann. Neurol. 53, 533-537. doi: 10.1002/ana.10557

Dauvilliers, Y., Arnulf, I., Szakacs, Z., Leu-Semenescu, S., Lecomte, I., Scart-Gres, C., et al. (2019). Long-term use of pitolisant to treat patients with narcolepsy: Harmony III Study. Sleep 42:zsz174.

Dauvilliers, Y., Bassetti, C., Lammers, G. J., Arnulf, I., Mayer, G., Rodenbeck, A., et al. (2013). Pitolisant versus placebo or modafinil in patients with narcolepsy: a double-blind, randomised trial. Lancet Neurol. 12, 1068-1075.

Dauvilliers, Y., Verbraecken, J., Partinen, M., Hedner, J., Saaresranta, T., Georgiev, O., et al. (2020). Pitolisant for daytime sleepiness in patients with obstructive sleep apnea who refuse continuous positive airway pressure treatment. A randomized trial. Am. J. Respir. Crit. Care Med. 201, 1135-1145.

Davis, L. K., Yu, D., Keenan, C. L., Gamazon, E. R., Konkashbaev, A. I., Derks, E. M., et al. (2013). Partitioning the heritability of Tourette syndrome and obsessive compulsive disorder reveals differences in genetic architecture. PLoS Genet. 9:e1003864. doi: 10.1371/journal.pgen.1003864

De Giorgi, R., De Crescenzo, F., D’alò, G. L., Rizzo Pesci, N., Di Franco, V., Sandini, C., et al. (2019). Prevalence of Non-affective psychoses in individuals with autism spectrum disorders: A systematic review. J. Clin. Med. 8:1304. doi: $10.3390 / \mathrm{jcm} 8091304$

Delay-Goyet, P., Blanchard, V., Schussler, N., Lopez-Grancha, M., Ménager, J., Mary, V., et al. (2016). SAR110894, a potent histamine H3-receptor antagonist, displays disease-modifying activity in a transgenic mouse model of tauopathy. Alzheimer's \& Dementia 2, 267-280. doi: 10.1016/j.trci.2016.10.002

del Rio, R., Noubade, R., Saligrama, N., Wall, E. H., Krementsov, D. N., Poynter, M. E., et al. (2012). Histamine H4 receptor optimizes T regulatory cell frequency and facilitates anti-inflammatory responses within the central nervous system. J. Immunol. 188, 541-547. doi: 10.4049/jimmunol.1101498

Deutsch, S. I., Rosse, R. B., Kendrick, K. A., Fay-Mccarthy, M., Collins, J. P. Jr., and Wyatt, R. J. (1993). Famotidine adjunctive pharmacotherapy for schizophrenia: preliminary data. Clin. Neuropharmacol. 16, 518-524.

Dong, H., Zhang, W., Zeng, X., Hu, G., Zhang, H., He, S., et al. (2014a). Histamine induces upregulated expression of histamine receptors and increases release of inflammatory mediators from microglia. Mol. Neurobiol. 49, 1487-1500. doi: 10.1007/s12035-014-8697-6

Dong, H., Zhang, X., and Qian, Y. (2014b). Mast cells and neuroinflammation. Med. Sci. Monitor Basic Res. 20, 200-206. doi: 10.12659/msmbr.893093

Dong, H., Zhang, X., Wang, Y., Zhou, X., Qian, Y., and Zhang, S. (2017). Suppression of brain mast cells degranulation inhibits microglial activation and central nervous system inflammation. Mol. Neurobiol. 54, 997-1007. doi: 10.1007/s12035-016-9720-x

Doreulee, N., Yanovsky, Y., Flagmeyer, I., Stevens, D. R., Haas, H. L., and Brown, R. E. (2001). Histamine $\mathrm{H}(3)$ receptors depress synaptic transmission in the corticostriatal pathway. Neuropharmacology 40, 106-113.

Drutel, G., Peitsaro, N., Karlstedt, K., Wieland, K., Smit, M. J., Timmerman, H., et al. (2001). Identification of rat $\mathrm{H} 3$ receptor isoforms with different brain expression and signaling properties. Mol. Pharmacol. 59, 1-8. doi: 10.1124/mol. 59.1.1

Dvorak, A. M. (1997). New aspects of mast cell biology. Int. Arch. Allergy Immunol. 114, 1-9. doi: 10.1159/000237635

Eiriz, M. F., Valero, J., Malva, J. O., and Bernardino, L. (2014). New insights into the role of histamine in subventricular zone-olfactory bulb neurogenesis. Front. Neurosci. 8:142. doi: 10.3389/fnins.2014.00142

Eissa, N., Al-Houqani, M., Sadeq, A., Ojha, S. K., Sasse, A., and Sadek, B. (2018a). Current enlightenment about etiology and pharmacological treatment of autism spectrum disorder. Front. Neurosci. 12:304. doi: 10.3389/fnins.2018. 00304

Eissa, N., Jayaprakash, P., Azimullah, S., Ojha, S. K., Al-Houqani, M., Jalal, F. Y., et al. (2018b). The histamine H3R antagonist DL77 attenuates autistic behaviors in a prenatal valproic acid-induced mouse model of autism. Sci. Rep. 8, 13077-13077.

Eissa, N., Azimullah, S., Jayaprakash, P., Jayaraj, R. L., Reiner, D., Ojha, S. K., et al. (2019). The dual-active histamine H3 receptor antagonist and acetylcholine esterase inhibitor E100 ameliorates stereotyped repetitive behavior and neuroinflammmation in sodium valproate induced autism in mice. Chem. Biol. Interact. 312:108775. doi: 10.1016/j.cbi.2019.108775
Eissa, N., Azimullah, S., Jayaprakash, P., Jayaraj, R. L., Reiner, D., Ojha, S. K., et al. (2020a). The dual-active Histamine $\mathrm{H}(3)$ receptor antagonist and acetylcholine esterase inhibitor E100 alleviates autistic-like behaviors and oxidative stress in valproic acid induced autism in mice. Int. J. Mol. Sci. 21:3996. doi: 10.3390/ ijms21113996

Eissa, N., Jayaprakash, P., Stark, H., Łażewska, D., Kieć-Kononowicz, K., and Sadek, B. (2020b). Simultaneous blockade of Histamine H(3) receptors and inhibition of acetylcholine esterase alleviate autistic-like behaviors in BTBR $\mathrm{T}+\mathrm{tf} / \mathrm{J}$ mouse model of autism. Biomolecules 10:1251. doi: 10.3390/biom10091251

Ellender, T. J., Huerta-Ocampo, I., Deisseroth, K., Capogna, M., and Bolam, J. P. (2011). Differential modulation of excitatory and inhibitory striatal synaptic transmission by histamine. J. Neurosci. 31, 15340-15351. doi: 10.1523/ jneurosci.3144-11.2011

Ercan-Sencicek, A. G., Stillman, A. A., Ghosh, A. K., Bilguvar, K., O’roak, B. J., Mason, C. E., et al. (2010). L-histidine decarboxylase and Tourette's syndrome. N. Engl. J. Med. 362, 1901-1908.

Esbenshade, T. A., Browman, K. E., Miller, T. R., Krueger, K. M., KomaterRoderwald, V., Zhang, M., et al. (2012). Pharmacological properties and procognitive effects of ABT-288, a potent and selective histamine $\mathrm{H} 3$ receptor antagonist. J. Pharmacol. Exp. Ther. 343, 233-245.

Escartin, C., Galea, E., Lakatos, A., O'callaghan, J. P., Petzold, G. C., SerranoPozo, A., et al. (2021). Reactive astrocyte nomenclature, definitions, and future directions. Nat. Neurosci. 24, 312-325.

Fang, Q., Xicoy, H., Shen, J., Luchetti, S., Dai, D., Zhou, P., et al. (2020). Histamine4 receptor antagonist ameliorates Parkinson-like pathology in the striatum. Brain Behav. Immun. 92, 127-138. doi: 10.1016/j.bbi.2020.11.036

Fernandez, T. V., Sanders, S. J., Yurkiewicz, I. R., Ercan-Sencicek, A. G., Kim, Y. S., Fishman, D. O., et al. (2012). Rare copy number variants in tourette syndrome disrupt genes in histaminergic pathways and overlap with autism. Biol. Psychiatry 71, 392-402. doi: 10.1016/j.biopsych.2011.09.034

Ferreira, R., Santos, T., Gonçalves, J., Baltazar, G., Ferreira, L., Agasse, F., et al. (2012). Histamine modulates microglia function. J. Neuroinflamm. 9:90.

Forsythe, P. (2019). Mast cells in neuroimmune interactions. Trends Neurosci. 42, 43-55. doi: 10.1016/j.tins.2018.09.006

Freeman, R. D., Fast, D. K., Burd, L., Kerbeshian, J., Robertson, M. M., and Sandor, P. (2000). An international perspective on Tourette syndrome: selected findings from 3,500 individuals in 22 countries. Dev. Med. Child Neurol. 42, 436-447. doi: 10.1111/j.1469-8749.2000.tb00346.x

Frick, L., Rapanelli, M., Abbasi, E., Ohtsu, H., and Pittenger, C. (2016). Histamine regulation of microglia: Gene-environment interaction in the regulation of central nervous system inflammation. Brain Behav. Immun. 57, 326-337. doi: 10.1016/j.bbi.2016.07.002

Fu, H., Liu, B., Frost, J. L., Hong, S., Jin, M., Ostaszewski, B., et al. (2012). Complement component $\mathrm{C} 3$ and complement receptor type 3 contribute to the phagocytosis and clearance of fibrillar A $\beta$ by microglia. Glia 60, 993-1003. doi: 10.1002/glia.22331

Galici, R., Boggs, J. D., Aluisio, L., Fraser, I. C., Bonaventure, P., Lord, B., et al. (2009). JNJ-10181457, a selective non-imidazole histamine H(3) receptor antagonist, normalizes acetylcholine neurotransmission and has efficacy in translational rat models of cognition. Neuropharmacology 56, 1131-1137. doi: 10.1016/j.neuropharm.2009.03.011

Galli, S. J., Kalesnikoff, J., Grimbaldeston, M. A., Piliponsky, A. M., Williams, C. M., and Tsai, M. (2005a). Mast cells as "tunable" effector and immunoregulatory cells: recent advances. Annu. Rev. Immunol. 23, 749-786. doi: 10.1146/annurev. immunol.21.120601.141025

Galli, S. J., Nakae, S., and Tsai, M. (2005b). Mast cells in the development of adaptive immune responses. Nat. Immunol. 6, 135-142. doi: 10.1038/ni1158

Garey, L. (2010). When cortical development goes wrong: schizophrenia as a neurodevelopmental disease of microcircuits. J. Anat. 217, 324-333. doi: 10. 1111/j.1469-7580.2010.01231.x

Gaspard, N., Bouschet, T., Hourez, R., Dimidschstein, J., Naeije, G., Van Den Ameele, J., et al. (2008). An intrinsic mechanism of corticogenesis from embryonic stem cells. Nature 455, 351-357. doi: 10.1038/nature07287

Gbahou, F., Vincent, L., Humbert-Claude, M., Tardivel-Lacombe, J., Chabret, C., and Arrang, J. M. (2006). Compared pharmacology of human histamine H3 and $\mathrm{H} 4$ receptors: structure-activity relationships of histamine derivatives. $\mathrm{Br}$. J. Pharmacol. 147, 744-754. doi: 10.1038/sj.bjp.0706666 
Genuneit, J., Braig, S., Brandt, S., Wabitsch, M., Florath, I., Brenner, H., et al. (2014). Infant atopic eczema and subsequent attention-deficit/hyperactivity disordera prospective birth cohort study. Pediatr. Allergy Immunol. 25, 51-56. doi: $10.1111 /$ pai.12152

Giannoccaro, M. P., Wright, S. K., and Vincent, A. (2019). In vivo mechanisms of antibody-mediated neurological disorders: animal models and potential implications. Front. Neurol. 10:1394. doi: 10.3389/fneur.2019.01394

Gilfillan, A. M., Austin, S. J., and Metcalfe, D. D. (2011). Mast cell biology: introduction and overview. Adv. Exp. Med. Biol. 716, 2-12. doi: 10.1007/9781-4419-9533-9_1

Ginhoux, F., Greter, M., Leboeuf, M., Nandi, S., See, P., Gokhan, S., et al. (2010). Fate mapping analysis reveals that adult microglia derive from primitive macrophages. Science 330, 841-845. doi: 10.1126/science.1194637

Graybiel, A. M., Aosaki, T., Flaherty, A. W., and Kimura, M. (1994). The basal ganglia and adaptive motor control. Science 265, 1826-1831. doi: 10.1126/ science. 8091209

Grillner, S., Hellgren, J., Menard, A., Saitoh, K., and Wikstrom, M. A. (2005). Mechanisms for selection of basic motor programs-roles for the striatum and pallidum. Trends Neurosci. 28, 364-370. doi: 10.1016/j.tins.2005.05.004

Grimbaldeston, M. A., Chen, C. C., Piliponsky, A. M., Tsai, M., Tam, S. Y., and Galli, S. J. (2005). Mast cell-deficient W-sash c-kit mutant Kit W-sh/W-sh mice as a model for investigating mast cell biology in vivo. Am. J. Pathol. 167, 835-848. doi: 10.1016/s0002-9440(10)62055- $\mathrm{x}$

Gupta, S., Ellis, S. E., Ashar, F. N., Moes, A., Bader, J. S., Zhan, J., et al. (2014). Transcriptome analysis reveals dysregulation of innate immune response genes and neuronal activity-dependent genes in autism. Nat. Commun. 5:5748.

Haas, H., and Panula, P. (2003). The role of histamine and the tuberomamillary nucleus in the nervous system. Nat. Rev. Neurosci. 4, 121-130. doi: 10.1038/ nrn1034

Haas, H. L., and Panula, P. (2016). Histamine receptors. Neuropharmacology 106, 1-2. doi: 10.1016/b978-0-7236-0589-8.50007-7

Haas, H. L., Sergeeva, O. A., and Selbach, O. (2008). Histamine in the nervous system. Physiol. Rev. 88, 1183-1241.

Hagiyama, M., Furuno, T., Hosokawa, Y., Iino, T., Ito, T., Inoue, T., et al. (2011). Enhanced nerve-mast cell interaction by a neuronal short isoform of cell adhesion molecule-1. J. Immunol. 186:5983. doi: 10.4049/jimmunol.1002244

Haig, G., Meier, A., Pritchett, Y., Hall, C., Gault, L., and Lenz, R. (2012). Evaluation of the efficacy and safety of the H3 antagonist ABT-288 in mild-to-moderate Alzheimer's disease. Alzheimer's Dementia 8, 601-602.

Haig, G. M., Bain, E., Robieson, W., Othman, A. A., Baker, J., and Lenz, R. A. (2014). A randomized trial of the efficacy and safety of the H3 antagonist ABT288 in cognitive impairment associated with schizophrenia. Schizophr. Bull. 40, 1433-1442. doi: 10.1093/schbul/sbt240

Halassa, M. M., Fellin, T., Takano, H., Dong, J.-H., and Haydon, P. G. (2007). Synaptic islands defined by the territory of a single astrocyte. J. Neurosci. 27:6473. doi: 10.1523/jneurosci.1419-07.2007

Halova, I., Draberova, L., and Draber, P. (2012). Mast cell chemotaxis chemoattractants and signaling pathways. Front. Immunol. 3:119. doi: 10.3389/ fimmu.2012.00119

Hamilton, N. B., and Attwell, D. (2010). Do astrocytes really exocytose neurotransmitters? Nat. Rev. Neurosci. 11, 227-238. doi: 10.1038/nrn2803

Han, S., Marquez-Gomez, R., Woodman, M., and Ellender, T. (2020). Histaminergic control of corticostriatal synaptic plasticity during early postnatal development. J. Neurosci. 40, 6557-6571. doi: 10.1523/jneurosci. 0740-20.2020

Harwell, V., and Fasinu, P. S. (2020). Pitolisant and other histamine-3 receptor antagonists-an update on therapeutic potentials and clinical prospects. Medicines (Basel) 7:55. doi: 10.3390/medicines7090055

Hendriksen, E., Van Bergeijk, D., Oosting, R. S., and Redegeld, F. A. (2017). Mast cells in neuroinflammation and brain disorders. Neurosci. Biobehav. Rev. 79, 119-133. doi: 10.1016/j.neubiorev.2017.05.001

Hofstra, C. L., Desai, P. J., Thurmond, R. L., and Fung-Leung, W. P. (2003). Histamine $\mathrm{H} 4$ receptor mediates chemotaxis and calcium mobilization of mast cells. J. Pharmacol. Exp. Ther. 305, 1212-1221. doi: 10.1124/jpet.102.046581

Hohn, V. D., De Veld, D. M. J., Mataw, K. J. S., Van Someren, E. J. W., and Begeer, S. (2019). Insomnia severity in adults with autism spectrum disorder is associated with sensory hyper-reactivity and social skill impairment. J. Autism Dev. Disord. 49, 2146-2155. doi: 10.1007/s10803-019-03891-8
Horner, W. E., Johnson, D. E., Schmidt, A. W., and Rollema, H. (2007). Methylphenidate and atomoxetine increase histamine release in rat prefrontal cortex. Eur. J. Pharmacol. 558, 96-97. doi: 10.1016/j.ejphar.2006.11.048

Hosli, E., and Hosli, L. (1984). Autoradiographic localization of binding sites for $[3 \mathrm{H}]$ histamine and $\mathrm{H} 1-$ and $\mathrm{H} 2$-antagonists on cultured neurones and glial cells. Neuroscience 13, 863-870. doi: 10.1016/0306-4522(84)90101-5

Hosli, L., Hosli, E., Schneider, U., and Wiget, W. (1984). Evidence for the existence of histamine $\mathrm{H} 1$ - and $\mathrm{H} 2$-receptors on astrocytes of cultured rat central nervous system. Neurosci. Lett. 48, 287-291. doi: 10.1016/0304-3940(84)90052-1

Howarth, C. (2014). The contribution of astrocytes to the regulation of cerebral blood flow. Front. Neurosci. 8:103. doi: 10.3389/fnins.2014.00103

Howe, J. R., Bear, M. F., Golshani, P., Klann, E., Lipton, S. A., Mucke, L., et al. (2018). The mouse as a model for neuropsychiatric drug development. Curr. Biol. 28, R909-R914.

Howes, O., Mccutcheon, R., and Stone, J. (2015). Glutamate and dopamine in schizophrenia: an update for the 21st century. J. Psychopharmacol. 29, 97-115. doi: $10.1177 / 0269881114563634$

Howes, O. D., Kambeitz, J., Kim, E., Stahl, D., Slifstein, M., Abi-Dargham, A., et al. (2012a). The nature of dopamine dysfunction in schizophrenia and what this means for treatment. Arch. Gen. Psychiatry 69, 776-786.

Howes, O. D., Vergunst, F., Gee, S., Mcguire, P., Kapur, S., and Taylor, D. (2012b). Adherence to treatment guidelines in clinical practice: study of antipsychotic treatment prior to clozapine initiation. Br. J. Psychiatry. 201, 481-485. doi: 10.1192/bjp.bp.111.105833

Howes, O. D., Williams, M., Ibrahim, K., Leung, G., Egerton, A., Mcguire, P. K., et al. (2013). Midbrain dopamine function in schizophrenia and depression: a post-mortem and positron emission tomographic imaging study. Brain 136, 3242-3251. doi: 10.1093/brain/awt264

Humbert-Claude, M., Davenas, E., Gbahou, F., Vincent, L., and Arrang, J. M. (2012). Involvement of histamine receptors in the atypical antipsychotic profile of clozapine: a reassessment in vitro and in vivo. Psychopharmacology 220, 225-241. doi: 10.1007/s00213-011-2471-5

Iida, T., Yoshikawa, T., Matsuzawa, T., Naganuma, F., Nakamura, T., Miura, Y., et al. (2015). Histamine H3 receptor in primary mouse microglia inhibits chemotaxis, phagocytosis, and cytokine secretion. Glia 63, 1213-1225.

Inocente, C., Arnulf, I., Bastuji, H., Thibault-Stoll, A., Raoux, A., Reimao, R., et al. (2012). Pitolisant, an inverse agonist of the histamine H3 receptor: an alternative stimulant for narcolepsy-cataplexy in teenagers with refractory sleepiness. Clin. Neuropharmacol. 35, 55-60. doi: 10.1097/wnf. 0b013e318246879d

Jalenques, I., Auclair, C., Morand, D., Legrand, G., Marcheix, M., Ramanoel, C., et al. (2017). Health-related quality of life, anxiety and depression in parents of adolescents with Gilles de la Tourette syndrome: a controlled study. Eur. Child Adolesc. Psychiatry 26, 603-617. doi: 10.1007/s00787-016-0923-5

Jarskog, L. F., Lowy, M. T., Grove, R. A., Keefe, R. S., Horrigan, J. P., Ball, M. P., et al. (2015). A Phase II study of a histamine H3 receptor antagonist GSK239512 for cognitive impairment in stable schizophrenia subjects on antipsychotic therapy. Schizophr. Res. 164, 136-142. doi: 10.1016/j.schres.2015.01.041

Jeffries, K. J., Schooler, C., Schoenbach, C., Herscovitch, P., Chase, T. N., and Braun, A. R. (2002). The functional neuroanatomy of Tourette's syndrome: an FDG PET study III: functional coupling of regional cerebral metabolic rates. Neuropsychopharmacology 27, 92-104. doi: 10.1016/s0893-133x(01)0 $0428-6$

Ji, K., Miyauchi, J., and Tsirka, S. E. (2013). Microglia: an active player in the regulation of synaptic activity. Neural. Plast. 2013:627325.

Jin, C. Y., Anichtchik, O., and Panula, P. (2009a). Altered histamine H3 receptor radioligand binding in post-mortem brain samples from subjects with psychiatric diseases. Br. J. Pharmacol. 157, 118-129. doi: 10.1111/j.1476-5381. 2009.00149.x

Jin, Y., Silverman, A. J., and Vannucci, S. J. (2009b). Mast cells are early responders after hypoxia-ischemia in immature rat brain. Stroke 40, 3107-3112. doi: 10. 1161/strokeaha.109.549691

Ji-Xu, A., and Vincent, A. (2020). Maternal immunity in autism spectrum disorders: questions of causality, validity, and specificity. J. Clin. Med. 9:2590. doi: $10.3390 / \mathrm{jcm} 9082590$

Johnson, D., and Krenger, W. (1992). Interactions of mast cells with the nervous system-recent advances. Neurochem. Res. 17, 939-951. doi: 10.1007/ bf00993271 
Jovevska, S., Richdale, A. L., Lawson, L. P., Uljarević, M., Arnold, S. R. C., and Trollor, J. N. (2020). Sleep quality in autism from adolescence to old age. Autism Adulthood 2, 152-162. doi: 10.1089/aut.2019.0034

Jurič, D. M., Krzan, M., and Lipnik-Stangelj, M. (2016). Histamine and astrocyte function. Pharmacol. Res. 111, 774-783. doi: 10.1016/j.phrs.2016.07.035

Jurič, D. M., Mele, T., and Carman-Krzan, M. (2011). Involvement of histaminergic receptor mechanisms in the stimulation of NT-3 synthesis in astrocytes. Neuropharmacology 60, 1309-1317. doi: 10.1016/j.neuropharm.2011. 01.019

Jutel, M., Watanabe, T., Klunker, S., Akdis, M., Thomet, O. A., Malolepszy, J., et al. (2001). Histamine regulates T-cell and antibody responses by differential expression of $\mathrm{H} 1$ and $\mathrm{H} 2$ receptors. Nature 413, 420-425. doi: 10.1038/ 35096564

Kalish, B. T., Kim, E., Finander, B., Duffy, E. E., Kim, H., Gilman, C. K., et al. (2021). Maternal immune activation in mice disrupts proteostasis in the fetal brain. Nat. Neurosci. 24, 204-213. doi: 10.1038/s41593-020-00762-9

Kalyva, E., Kyriazi, M., Vargiami, E., and Zafeiriou, D. (2016). A review of cooccurrence of autism spectrum disorder and Tourette syndrome. Res. Autism Spectrum Disord. 24, 39-51. doi: 10.1016/j.rasd.2016.01.007

Kaminsky, R., Moriarty, T. M., Bodine, J., Wolf, D. E., and Davidson, M. (1990). Effect of famotidine on deficit symptoms of schizophrenia. Lancet 335, 13511352. doi: 10.1016/0140-6736(90)91237-5

Karagiannidis, I., Dehning, S., Sandor, P., Tarnok, Z., Rizzo, R., Wolanczyk, T., et al. (2013). Support of the histaminergic hypothesis in Tourette syndrome: association of the histamine decarboxylase gene in a large sample of families. J. Med. Genet. 50, 760-764. doi: 10.1136/jmedgenet-2013-101637

Karlstedt, K., Ahman, M. J., Anichtchik, O. V., Soinila, S., and Panula, P. (2003). Expression of the $\mathrm{H} 3$ receptor in the developing CNS and brown fat suggests novel roles for histamine. Mol. Cell Neurosci. 24, 614-622. doi: 10.1016/s10447431(03)00208-2

Karlstedt, K., Nissinen, M., Michelsen, K. A., and Panula, P. (2001a). Multiple sites of L-histidine decarboxylase expression in mouse suggest novel developmental functions for histamine. Dev. Dyn. 221, 81-91. doi: 10.1002/dvdy.1127

Karlstedt, K., Senkas, A., Ahman, M., and Panula, P. (2001b). Regional expression of the histamine $\mathrm{H}(2)$ receptor in adult and developing rat brain. Neuroscience 102, 201-208. doi: 10.1016/s0306-4522(00)00464-4

Karpati, A., Yoshikawa, T., Nakamura, T., Iida, T., Matsuzawa, T., Kitano, H., et al. (2018). Histamine elicits glutamate release from cultured astrocytes. J. Pharmacol. Sci. 137, 122-128. doi: 10.1016/j.jphs.2018.05.002

Kasteleijn-Nolst Trenite, D., Parain, D., Genton, P., Masnou, P., Schwartz, J. C., and Hirsch, E. (2013). Efficacy of the histamine 3 receptor (H3R) antagonist pitolisant (formerly known as tiprolisant; BF2.649) in epilepsy: dose-dependent effects in the human photosensitivity model. Epilepsy Behav. 28, 66-70. doi: 10.1016/j.yebeh.2013.03.018

Katoh, Y., Niimi, M., Yamamoto, Y., Kawamura, T., Morimoto-Ishizuka, T., Sawada, M., et al. (2001). Histamine production by cultured microglial cells of the mouse. Neurosci. Lett. 305, 181-184. doi: 10.1016/s0304-3940(01)01835-3

Kempuraj, D., Thangavel, R., Selvakumar, G. P., Ahmed, M. E., Zaheer, S., Raikwar, S. P., et al. (2019). Mast cell proteases activate Astrocytes and Glia-Neurons and Release Interleukin-33 by activating p 38 and ERK1/2 MAPKs and NF-кB. Mol. Neurobiol. 56, 1681-1693. doi: 10.1007/s12035-018-1177-7

Kettenmann, H., Hanisch, U. K., Noda, M., and Verkhratsky, A. (2011). Physiology of microglia. Physiol. Rev. 91, 461-553.

Khalil, M., Ronda, J., Weintraub, M., Jain, K., Silver, R., and Silverman, A.-J. (2007). Brain mast cell relationship to neurovasculature during development. Brain Res. 1171, 18-29. doi: 10.1016/j.brainres.2007.07.034

Kim, D. Y., Jeoung, D., and Ro, J. Y. (2010). Signaling pathways in the activation of mast cells cocultured with astrocytes and colocalization of both cells in experimental allergic encephalomyelitis. J. Immunol. 185, 273-283. doi: 10. 4049/jimmunol.1000991

Kim, S., Kim, H., Yim, Y. S., Ha, S., Atarashi, K., Tan, T. G., et al. (2017). Maternal gut bacteria promote neurodevelopmental abnormalities in mouse offspring. Nature 549, 528-532. doi: 10.1038/nature23910

Kinnunen, A., Lintunen, M., Karlstedt, K., Fukui, H., and Panula, P. (1998). In situ detection of H1-receptor mRNA and absence of apoptosis in the transient histamine system of the embryonic rat brain. J. Comp. Neurol. 394, 127-137. doi: 10.1002/(sici)1096-9861(19980427)394:1<127::aid-cne10>3.0.co;2-1
Kitamura, Y., Go, S., and Hatanaka, K. (1978). Decrease of mast cells in W/Wv mice and their increase by bone marrow transplantation. Blood 52, 447-452. doi: 10.1182/blood.v52.2.447.447

Knuesel, I., Chicha, L., Britschgi, M., Schobel, S. A., Bodmer, M., Hellings, J. A., et al. (2014). Maternal immune activation and abnormal brain development across CNS disorders. Nat. Rev. Neurol. 10, 643-660. doi: 10.1038/nrneurol. 2014.187

Korn, T., and Kallies, A. (2017). T cell responses in the central nervous system. Nat. Rev. Immunol. 17, 179-194. doi: 10.1038/nri.2016.144

Kozorovitskiy, Y., Saunders, A., Johnson, C. A., Lowell, B. B., and Sabatini, B. L. (2012). Recurrent network activity drives striatal synaptogenesis. Nature 485, 646-650. doi: 10.1038/nature11052

Krajeski, R. N., Macey-Dare, A., Van Heusden, F., Ebrahimjee, F., and Ellender, T. J. (2019). Dynamic postnatal development of the cellular and circuit properties of striatal D1 and D2 spiny projection neurons. J. Physiol. 597, 5265-5293. doi: $10.1113 /$ jp278416

Kreitzer, A. C., and Malenka, R. C. (2008). Striatal plasticity and basal ganglia circuit function. Neuron 60, 543-554. doi: 10.1016/j.neuron.2008.11.005 N., et al. (2015). The breadth and type of systemic inflammation and the risk of adverse neurological outcomes in extremely low gestation newborns. Pediatr. Neurol. 52, 42-48. doi: 10.1016/j.pediatrneurol.2014.10.005

Kulka, M., Sheen, C. H., Tancowny, B. P., Grammer, L. C., and Schleimer, R. P. (2008). Neuropeptides activate human mast cell degranulation and chemokine production. Immunology 123, 398-410. doi: 10.1111/j.1365-2567.2007. 02705.x

Lai, C. S., Fisher, S. E., Hurst, J. A., Vargha-Khadem, F., and Monaco, A. P. (2001). A forkhead-domain gene is mutated in a severe speech and language disorder. Nature 413, 519-523. doi: 10.1038/35097076

Lawson, L. J., Perry, V. H., and Gordon, S. (1992). Turnover of resident microglia in the normal adult mouse brain. Neuroscience 48, 405-415. doi: 10.1016/03064522(92)90500-2

Lee, A. S., Azmitia, E. C., and Whitaker-Azmitia, P. M. (2017). Developmental microglial priming in postmortem autism spectrum disorder temporal cortex. Brain Behav. Immun. 62, 193-202. doi: 10.1016/j.bbi.2017.01.019

Lei, J., Deng, X., Zhang, J., Su, L., Xu, H., Liang, H., et al. (2012). Mutation screening of the HDC gene in Chinese han patients with Tourette syndrome. Am. J. Med. Genet. B Neuropsychiatr. Genet. 159b, 72-76. doi: 10.1002/ajmg.b. 32003

Lennington, J. B., Coppola, G., Kataoka-Sasaki, Y., Fernandez, T. V., Palejev, D., Li, Y., et al. (2016). Transcriptome analysis of the human striatum in tourette syndrome. Biol. Psychiatry 79, 372-382. doi: 10.1016/j.biopsych.2014.07.018

Lenz, K. M., Pickett, L. A., Wright, C. L., Davis, K. T., Joshi, A., and Mccarthy, M. M. (2018). Mast cells in the developing brain determine adult sexual behavior. J. Neurosci. 38, 8044-8059. doi: 10.1523/jneurosci.1176-18.2018

Leurs, R., Bakker, R. A., Timmerman, H., and De Esch, I. J. (2005). The histamine $\mathrm{H} 3$ receptor: from gene cloning to $\mathrm{H} 3$ receptor drugs. Nat. Rev. Drug Discov. 4, 107-120. doi: 10.1038/nrd1631

Li, X., Chauhan, A., Sheikh, A. M., Patil, S., Chauhan, V., Li, X. M., et al. (2009). Elevated immune response in the brain of autistic patients. J. Neuroimmunol. 207, 111-116. doi: 10.1016/j.jneuroim.2008.12.002

Lichanska, A. M., and Hume, D. A. (2000). Origins and functions of phagocytes in the embryo. Exper. Hematol. 28, 601-611. doi: 10.1016/s0301-472x(00)0 0157-0

Lin, J. S., Anaclet, C., Sergeeva, O. A., and Haas, H. L. (2011). The waking brain: an update. Cell Mol. Life Sci. 68, 2499-2512. doi: 10.1007/s00018-011-0631-8

Lin, J. S., Dauvilliers, Y., Arnulf, I., Bastuji, H., Anaclet, C., Parmentier, R., et al. (2008). An inverse agonist of the histamine $\mathrm{H}(3)$ receptor improves wakefulness in narcolepsy: studies in orexin-/- mice and patients. Neurobiol. Dis. 30, 74-83. doi: 10.1016/j.nbd.2007.12.003

Linday, L. A., Tsiouris, J. A., Cohen, I. L., Shindledecker, R., and Decresce, R. (2001). Famotidine treatment of children with autistic spectrum disorders: pilot research using single subject research design. J. Neural. Transm. 108, 593-611. doi: $10.1007 / \mathrm{s} 007020170059$

Lipnik-Stangelj, M., and Carman-Krzan, M. (2004). Activation of histamine H1receptor enhances neurotrophic factor secretion from cultured astrocytes. Inflamm. Res. 53, 245-252. doi: 10.1007/s00011-004-1247-3 
Lipnik-Štangelj, M., and Čarman-Kržan, M. (2005). Histamine and IL-6 interaction in the stimulation of nerve growth factor secretion from cultured astrocytes. Inflamm. Res. 54, S36-S37. doi: 10.1007/s00011-004-0416-8

Lipnik-Stangelj, M., and Carman-Krzan, M. (2006). Effects of histamine and IL-1beta on PKC-stimulated nerve growth factor secretion from glial cells. Inflamm. Res. 55, S34-S35.

Luo, Y., Weibman, D., Halperin, J. M., and Li, X. (2019). A review of Heterogeneity in Attention Deficit/Hyperactivity Disorder (ADHD). Front. Hum. Neurosci. 13:42. doi: 10.3389 /fnhum.2019.00042

Matson, J. L., and Shoemaker, M. (2009). Intellectual disability and its relationship to autism spectrum disorders. Res. Dev. Disabil. 30, 1107-1114.

Mehta, V. S., and Ram, D. (2014). Role of ranitidine in negative symptoms of schizophrenia-an open label study. Asian J. Psychiatr. 12, 150-154. doi: 10. 1016/j.ajp.2014.08.005

Mendes, M. S., and Majewska, A. K. (2021). An overview of microglia ontogeny and maturation in the homeostatic and pathological brain. Eur. J. Neurosci. 53, 3525-3547. doi: 10.1111/ejn.15225

Meskanen, K., Ekelund, H., Laitinen, J., Neuvonen, P. J., Haukka, J., Panula, P., et al. (2013). A randomized clinical trial of histamine 2 receptor antagonism in treatment-resistant schizophrenia. J. Clin. Psychopharmacol. 33, 472-478. doi: 10.1097/jcp.0b013e3182970490

Molina-Hernández, A., Diaz, N. F., and Arias-Montano, J. A. (2012). Histamine in brain development. J. Neurochem. 122, 872-882. doi: 10.1111/j.1471-4159. 2012.07863.x

Molina-Hernández, A., Nunez, A., Sierra, J. J., and Arias-Montano, J. A. (2001). Histamine $\mathrm{H} 3$ receptor activation inhibits glutamate release from rat striatal synaptosomes. Neuropharmacology 41, 928-934. doi: 10.1016/s0028-3908(01) 00144-7

Molina-Hernández, A., and Velasco, I. (2008). Histamine induces neural stem cell proliferation and neuronal differentiation by activation of distinct histamine receptors. J. Neurochem. 106, 706-717. doi: 10.1111/j.1471-4159.2008. 05424.x

Morgan, J. T., Chana, G., Pardo, C. A., Achim, C., Semendeferi, K., Buckwalter, J., et al. (2010). Microglial activation and increased microglial density observed in the dorsolateral prefrontal cortex in autism. Biol. Psychiatry 68, 368-376. doi: 10.1016/j.biopsych.2010.05.024

Mortimer, A. M., Singh, P., Shepherd, C. J., and Puthiryackal, J. (2010). Clozapine for treatment-resistant schizophrenia: National Institute of Clinical Excellence (NICE) guidance in the real world. Clin. Schizophr. Relat. Psychoses 4, 49-55. doi: $10.3371 /$ csrp.4.1.4

Munakata, M., and Akaike, N. (1994). Regulation of K+ conductance by histamine $\mathrm{H} 1$ and $\mathrm{H} 2$ receptors in neurones dissociated from rat neostriatum. J. Physiol. 480, 233-245. doi: 10.1113/jphysiol.1994.sp020356

Nathan, P. J., Boardley, R., Scott, N., Berges, A., Maruff, P., Sivananthan, T., et al. (2013). The safety, tolerability, pharmacokinetics and cognitive effects of GSK239512, a selective histamine (H3) receptor antagonist in patients with mild to moderate Alzheimer's disease: a preliminary investigation. Curr. Alzheimer Res. 10, 240-251. doi: 10.2174/1567205011310030003

Nedergaard, M., Ransom, B., and Goldman, S. A. (2003). New roles for astrocytes: redefining the functional architecture of the brain. Trends Neurosci. 26, 523530. doi: $10.1016 /$ j.tins.2003.08.008

Nelissen, S., Lemmens, E., Geurts, N., Kramer, P., Maurer, M., Hendriks, J., et al. (2013). The role of mast cells in neuroinflammation. Acta Neuropathol. 125, 637-650. doi: 10.1007/s00401-013-1092-y

Nissinen, M. J., Karlstedt, K., Castrén, E., and Panula, P. (1995). Expression of histidine decarboxylase and cellular histamine-like immunoreactivity in rat embryogenesis. J. Histochem. Cytochem. 43, 1241-1252. doi: 10.1177/43.12. 8537641

Nissinen, M. J., and Panula, P. (1995). Developmental patterns of histamine-like immunoreactivity in the mouse. J. Histochem. Cytochem. 43, 211-227. doi: 10.1177/43.2.7822777

Ohtsu, H., Tanaka, S., Terui, T., Hori, Y., Makabe-Kobayashi, Y., Pejler, G., et al. (2001). Mice lacking histidine decarboxylase exhibit abnormal mast cells. FEBS Lett. 502, 53-56. doi: 10.1016/s0014-5793(01)02663-1

Olsen, M. L., Khakh, B. S., Skatchkov, S. N., Zhou, M., Lee, C. J., and Rouach, N. (2015). New insights on astrocyte ion channels: critical for homeostasis and neuron-glia signaling. J. Neurosci. 35:13827. doi: 10.1523/jneurosci.2603-15. 2015
Orsetti, M., Ghi, P., and Di Carlo, G. (2001). Histamine H(3)-receptor antagonism improves memory retention and reverses the cognitive deficit induced by scopolamine in a two-trial place recognition task. Behav. Brain Res. 124, 235-242. doi: 10.1016/s0166-4328(01)00216-9

O'shea, T. M., Shah, B., Allred, E. N., Fichorova, R. N., Kuban, K. C. K., Dammann, O., et al. (2013). Inflammation-initiating illnesses, inflammationrelated proteins, and cognitive impairment in extremely preterm infants. Brain Behav. Immun. 29, 104-112. doi: 10.1016/j.bbi.2012.12.012

Ossola, B., Schendzielorz, N., Chen, S. H., Bird, G. S., Tuominen, R. K., Männistö, P. T., et al. (2011). Amantadine protects dopamine neurons by a dual action: reducing activation of microglia and inducing expression of GDNF in astroglia [corrected]. Neuropharmacology 61, 574-582. doi: 10.1016/j.neuropharm.2011. 04.030

Othman, A. A., Haig, G., Florian, H., Locke, C., Gertsik, L., and Dutta, S. (2014). The H3 antagonist ABT-288 is tolerated at significantly higher exposures in subjects with schizophrenia than in healthy volunteers. Br. J. Clin. Pharmacol. 77, 965-974. doi: 10.1111/bcp.12281

Othman, A. A., Haig, G., Florian, H., Locke, C., Zhang, J., and Dutta, S. (2013). Safety, tolerability and pharmacokinetics of the histamine $\mathrm{H} 3$ receptor antagonist, ABT-288, in healthy young adults and elderly volunteers. Br. J. Clin. Pharmacol. 75, 1299-1311. doi: 10.1111/j.1365-2125.2012.04472.x

Oyewumi, L. K., Vollick, D., Merskey, H., and Plumb, C. (1994). Famotidine as an adjunct treatment of resistant schizophrenia. J. Psychiatry Neurosci. 19, 145-150.

Panula, P., Chazot, P. L., Cowart, M., Gutzmer, R., Leurs, R., Liu, W. L., et al. (2015). International union of basic and clinical pharmacology. XCVIII. Histamine receptors. Pharmacol. Rev. 67,601-655. doi: 10.1124/pr.114.010249

Panula, P., and Nuutinen, S. (2013). The histaminergic network in the brain: basic organization and role in disease. Nat. Rev. Neurosci. 14, 472-487. doi: 10.1038/nrn3526

Panula, P., Sundvik, M., and Karlstedt, K. (2014). Developmental roles of brain histamine. Trends Neurosci. 37, 159-168. doi: 10.1016/j.tins.2014.01.001

Paolicelli, R. C., Bolasco, G., Pagani, F., Maggi, L., Scianni, M., Panzanelli, P., et al. (2011). Synaptic pruning by microglia is necessary for normal brain development. Science 333, 1456-1458. doi: 10.1126/science.1202529

Parkhurst, C. N., Yang, G., Ninan, I., Savas, J. N., Yates, J. R. III, Lafaille, J. J., et al. (2013). Microglia promote learning-dependent synapse formation through brain-derived neurotrophic factor. Cell 155, 1596-1609. doi: 10.1016/j.cell. 2013.11.030

Parpura, V., Basarsky, T. A., Liu, F., Jeftinija, K., Jeftinija, S., and Haydon, P. G. (1994). Glutamate-mediated astrocyte-neuron signalling. Nature 369, 744-747. doi: $10.1038 / 369744 \mathrm{a} 0$

Parra-Abarca, J., Rivera-Ramirez, N., Villa-Maldonado, L. F., GarciaHernandez, U., Aguilera, P., and Arias-Montano, J. A. (2019). Histamine $\mathrm{H} 1$ and $\mathrm{H} 3$ receptor activation increases the expression of Glucose Transporter 1 (GLUT-1) in rat cerebro-cortical astrocytes in primary culture. Neurochem. Int. 131:104565. doi: 10.1016/j.neuint.2019.10 4565

Pasciuto, E., Burton, O. T., Roca, C. P., Lagou, V., Rajan, W. D., Theys, T., et al. (2020). Microglia require CD4 T cells to complete the fetal-to-adult transition. Cell 182, 625-640. doi: 10.1016/j.cell.2020.06.026

Passani, M. B., and Blandina, P. (2011). Histamine receptors in the CNS as targets for therapeutic intervention. Trends Pharmacol. Sci. 32, 242-249. doi: 10.1016/ j.tips.2011.01.003

Passani, M. B., Panula, P., and Lin, J. S. (2014). Histamine in the brain. Front. Syst. Neurosci. 8:64. doi: 10.3389/fnsys.2014.00064

Patel, S., Dale, R. C., Rose, D., Heath, B., Nordahl, C. W., Rogers, S., et al. (2020). Maternal immune conditions are increased in males with autism spectrum disorders and are associated with behavioural and emotional but not cognitive co-morbidity. Transl. Psychiatry 10:286.

Patnaik, R., Sharma, A., Skaper, S. D., Muresanu, D. F., Lafuente, J. V., Castellani, R. J., et al. (2018). Histamine H3 inverse agonist BF 2649 or antagonist with partial H4 agonist activity clobenpropit reduces amyloid beta peptide-induced brain pathology in Alzheimer's Disease. Mol. Neurobiol. 55, 312-321. doi: 10.1007/s12035-017-0743-8

Patterson, P. H. (2009). Immune involvement in schizophrenia and autism: etiology, pathology and animal models. Behav. Brain Res. 204, 313-321. doi: 10.1016/j.bbr.2008.12.016 
Peixoto, R. T., Chantranupong, L., Hakim, R., Levasseur, J., Wang, W., Merchant, T., et al. (2019). Abnormal striatal development underlies the early onset of behavioral deficits in shank3B(-/-) mice. Cell Rep. 29, 2016-2027. doi: 10. 1016/j.celrep.2019.10.021

Peixoto, R. T., Wang, W., Croney, D. M., Kozorovitskiy, Y., and Sabatini, B. L. (2016). Early hyperactivity and precocious maturation of corticostriatal circuits in Shank3B(-/-) mice. Nat. Neurosci. 19, 716-724. doi: 10.1038/nn. 4260

Prast, H., Tran, M. H., Lamberti, C., Fischer, H., Kraus, M., Grass, K., et al. (1999). Histaminergic neurons modulate acetylcholine release in the ventral striatum: role of $\mathrm{H} 1$ and $\mathrm{H} 2$ histamine receptors. Naunyn Schmiedebergs Arch. Pharmacol. 360, 552-557. doi: 10.1007/s002109900098

Prat, C. S., Stocco, A., Neuhaus, E., and Kleinhans, N. M. (2016). Basal ganglia impairments in autism spectrum disorder are related to abnormal signal gating to prefrontal cortex. Neuropsychologia 91, 268-281. doi: 10.1016/j. neuropsychologia.2016.08.007

Prell, G. D., Green, J. P., Elkashef, A. M., Khandelwal, J. K., Linnoila, M., Wyatt, R. J., et al. (1996). The relationship between urine excretion and biogenic amines and their metabolites in cerebrospinal fluid of schizophrenic patients. Schizophr. Res. 19, 171-176. doi: 10.1016/0920-9964(96)88524-0

Prell, G. D., Green, J. P., Kaufmann, C. A., Khandelwal, J. K., Morrishow, A. M., Kirch, D. G., et al. (1995). Histamine metabolites in cerebrospinal fluid of patients with chronic schizophrenia: their relationships to levels of other aminergic transmitters and ratings of symptoms. Schizophr. Res. 14, 93-104. doi: 10.1016/0920-9964(94)00034-6

Pullen, L. C., Picone, M., Tan, L., Johnston, C., and Stark, H. (2019). Cognitive improvements in children with prader-willi syndrome following pitolisant treatment-patient reports. J. Pediatr. Pharmacol. Ther. 24, 166-171. doi: 10. 5863/1551-6776-24.2.166

Puttonen, H. A. J., Semenova, S., Sundvik, M., and Panula, P. (2017). Storage of neural histamine and histaminergic neurotransmission is VMAT2 dependent in the zebrafish. Sci. Rep. 7:3060.

Ramaglia, V., Hughes, T. R., Donev, R. M., Ruseva, M. M., Wu, X., Huitinga, I., et al. (2012). C3-dependent mechanism of microglial priming relevant to multiple sclerosis. Proc. Natl. Acad. Sci. U S A. 109, 965-970. doi: 10.1073/pnas. 1111924109

Rapanelli, M., Frick, L., Pogorelov, V., Ohtsu, H., Bito, H., and Pittenger, C. (2017). Histamine $\mathrm{H} 3 \mathrm{R}$ receptor activation in the dorsal striatum triggers stereotypies in a mouse model of tic disorders. Transl. Psychiatry 7, e1013. doi: 10.1038/tp. 2016.290

Rapanelli, M., Frick, L. R., Horn, K. D., Schwarcz, R. C., Pogorelov, V., Nairn, A. C., et al. (2016). The Histamine H3 receptor differentially modulates Mitogen-activated Protein Kinase (MAPK) and akt signaling in striatonigral and striatopallidal neurons. J. Biol. Chem. 291, 21042-21052. doi: 10.1074/jbc. m116.731406

Reed, M. D., Yim, Y. S., Wimmer, R. D., Kim, H., Ryu, C., Welch, G. M., et al. (2020). IL-17a promotes sociability in mouse models of neurodevelopmental disorders. Nature 577, 249-253. doi: 10.1038/s41586-019-1843-6

Reemst, K., Noctor, S. C., Lucassen, P. J., and Hol, E. M. (2016). The indispensable roles of microglia and astrocytes during brain development. Front. Hum. Neurosci. 10:566. doi: 10.3389/fnhum.2016.00566

Reiner, D., Seifert, L., Deck, C., Schüle, R., Jung, M., and Stark, H. (2020). Epigenetics meets GPCR: inhibition of histone H3 methyltransferase (G9a) and histamine H3 receptor for Prader-willi syndrome. Sci. Rep. 10:13558.

Reisinger, S., Khan, D., Kong, E., Berger, A., Pollak, A., and Pollak, D. D. (2015). The poly(I:C)-induced maternal immune activation model in preclinical neuropsychiatric drug discovery. Pharmacol. Ther. 149, 213-226. doi: 10.1016/ j.pharmthera.2015.01.001

Reuter, U., Bolay, H., Jansen-Olesen, I., Chiarugi, A., Sanchez Del Rio, M., Letourneau, R., et al. (2001). Delayed inflammation in rat meninges: implications for migraine pathophysiology. Brain 124, 2490-2502. doi: 10. 1093/brain/124.12.2490

Ricci, G., Volpi, L., Pasquali, L., Petrozzi, L., and Siciliano, G. (2009). Astrocyteneuron interactions in neurological disorders. J. Biol. Phys. 35, 317-336. doi: 10.1007/s10867-009-9157-9

Robertson, M. M. (2000). Tourette syndrome, associated conditions and the complexities of treatment. Brain 123, 425-462. doi: 10.1093/brain/123.3.425
Rocha, S. M., Cristovao, A. C., Campos, F. L., Fonseca, C. P., and Baltazar, G. (2012). Astrocyte-derived GDNF is a potent inhibitor of microglial activation. Neurobiol. Dis. 47, 407-415. doi: 10.1016/j.nbd.2012.04.014

Rocha, S. M., Saraiva, T., Cristóvão, A. C., Ferreira, R., Santos, T., Esteves, M., et al. (2016). Histamine induces microglia activation and dopaminergic neuronal toxicity via H1 receptor activation. J. Neuroinflamm. 13:137.

Rodriguez, J. I., and Kern, J. K. (2011). Evidence of microglial activation in autism and its possible role in brain underconnectivity. Neuron Glia Biol. 7, 205-213. doi: $10.1017 / \mathrm{s} 1740925 \times 12000142$

Rodríguez-Martínez, G., Velasco, I., Garcia-Lopez, G., Solis, K. H., Flores-Herrera, H., Diaz, N. F., et al. (2012). Histamine is required during neural stem cell proliferation to increase neuron differentiation. Neuroscience 216, 10-17. doi: 10.1016/j.neuroscience.2012.04.049

Roman, C., Egert, L., and Di Benedetto, B. (2020). Astrocytic-neuronal crosstalk gets jammed: Alternative perspectives on the onset of neuropsychiatric disorders. Eur. J. Neurosci. 9:e14900.

Romijn, H. J., Hofman, M. A., and Gramsbergen, A. (1991). At what age is the developing cerebral cortex of the rat comparable to that of the full-term newborn human baby? Early Hum. Dev. 26, 61-67. doi: 10.1016/0378-3782(91) 90044-4

Rosa, A. C., and Fantozzi, R. (2013). The role of histamine in neurogenic inflammation. Br. J. Pharmacol. 170, 38-45. doi: 10.1111/bph.12266

Rosin, J. M., Marsters, C. M., Malik, F., Far, R., Adnani, L., Schuurmans, C., et al. (2021a). Embryonic microglia interact with hypothalamic radial glia during development and upregulate the TAM receptors MERTK and AXL following an Insult. Cell Rep. 34:108587. doi: 10.1016/j.celrep.2020.108587

Rosin, J. M., Sinha, S., Biernaskie, J., and Kurrasch, D. M. (2021b). A subpopulation of embryonic microglia respond to maternal stress and influence nearby neural progenitors. Dev. Cell 56, 1326-1345. doi: 10.1016/j.devcel.2021.03.018

Rosse, R. B., Kendrick, K., Tsui, L. C., Fay-Mccarthy, M., Collins, J. P., Rosenberg, P., et al. (1995). Famotidine adjunctive pharmacotherapy of schizophrenia: A case report. Clin. Neuropharmacol. 18, 369-374. doi: 10.1097/00002826199508000-00009

Rothhammer, V., and Quintana, F. J. (2015). Control of autoimmune CNS inflammation by astrocytes. Semin. Immunopathol. 37, 625-638. doi: 10.1007/ s00281-015-0515-3

Rusjan, P., Sabioni, P., Di Ciano, P., Mansouri, E., Boileau, I., Laveillé, A., et al. (2020). Exploring occupancy of the histamine $\mathrm{H}(3)$ receptor by pitolisant in humans using PET. Br. J. Pharmacol. 177, 3464-3472. doi: 10.1111/bph.15067

Rustenhoven, J., Drieu, A., Mamuladze, T., De Lima, K. A., Dykstra, T., Wall, M., et al. (2021). Functional characterization of the dural sinuses as a neuroimmune interface. Cell 184, 1000-1016. doi: 10.1016/j.cell.2020.12.040

Sadek, B., Schwed, J. S., Subramanian, D., Weizel, L., Walter, M., Adem, A., et al. (2014). Non-imidazole histamine H3 receptor ligands incorporating antiepileptic moieties. Eur. J. Med. Chem. 77, 269-279. doi: 10.1016/j.ejmech. 2014.03.014

Saha, S., Chant, D., Welham, J., and Mcgrath, J. (2005). A systematic review of the prevalence of schizophrenia. PLoS Med. 2:e141. doi: 10.1371/journal.pmed. 0020141

Salter, M. W., and Stevens, B. (2017). Microglia emerge as central players in brain disease. Nat. Med. 23, 1018-1027. doi: 10.1038/nm.4397

Salvador, A. F., De Lima, K. A., and Kipnis, J. (2021). Neuromodulation by the immune system: a focus on cytokines. Nat. Rev. Immunol. doi: 10.1038/s41577021-00508-z

Saraiva, C., Barata-Antunes, S., Santos, T., Ferreiro, E., Cristovao, A. C., SerraAlmeida, C., et al. (2019). Histamine modulates hippocampal inflammation and neurogenesis in adult mice. Sci. Rep. 9:8384.

Sauvageot, C. M., and Stiles, C. D. (2002). Molecular mechanisms controlling cortical gliogenesis. Curr. Opin. Neurobiol. 12, 244-249. doi: 10.1016/s09594388(02)00322-7

Schafer, D. P., Lehrman, E. K., Kautzman, A. G., Koyama, R., Mardinly, A. R., Yamasaki, R., et al. (2012). Microglia sculpt postnatal neural circuits in an activity and complement-dependent manner. Neuron 74, 691-705. doi: 10. 1016/j.neuron.2012.03.026

Schafer, D. P., and Stevens, B. (2013). Phagocytic glial cells: sculpting synaptic circuits in the developing nervous system. Curr. Opin. Neurobiol. 23, 10341040. doi: 10.1016/j.conb.2013.09.012 
Scheller, J., Chalaris, A., Schmidt-Arras, D., and Rose-John, S. (2011). The pro- and anti-inflammatory properties of the cytokine interleukin-6. Biochim. Biophys. Acta 1813, 878-888.

Schlicker, E., Fink, K., Detzner, M., and Gothert, M. (1993). Histamine inhibits dopamine release in the mouse striatum via presynaptic $\mathrm{H} 3$ receptors. J. Neural. Transm. Gen. Sect. 93, 1-10. doi: 10.1007/bf01244933

Schneider, E. H., and Seifert, R. (2016). The histamine H4-receptor and the central and peripheral nervous system: A critical analysis of the literature. Neuropharmacology 106, 116-128. doi: 10.1016/j.neuropharm.2015.05.004

Schwartz, J. C., Arrang, J. M., Garbarg, M., Pollard, H., and Ruat, M. (1991). Histaminergic transmission in the mammalian brain. Physiol. Rev. 71, 1-51. doi: 10.1152/physrev.1991.71.1.1

Schwartz, L. B. (1987). Mediators of human mast cells and human mast cell subsets. Ann. Allergy 58, 226-235.

Sellgren, C. M., Gracias, J., Watmuff, B., Biag, J. D., Thanos, J. M., Whittredge, P. B., et al. (2019). Increased synapse elimination by microglia in schizophrenia patient-derived models of synaptic pruning. Nat. Neurosci. 22, 374-385. doi: 10.1038/s41593-018-0334-7

Shan, L., Bao, A. M., and Swaab, D. F. (2015). The human histaminergic system in neuropsychiatric disorders. Trends Neurosci. 38, 167-177. doi: 10.1016/j.tins. 2014.12.008

Sierra, A., Abiega, O., Shahraz, A., and Neumann, H. (2013). Janus-faced microglia: beneficial and detrimental consequences of microglial phagocytosis. Front. Cell Neurosci. 7:6. doi: 10.3389/fncel.2013.00006

Silver, R., and Curley, J. P. (2013). Mast cells on the mind: new insights and opportunities. Trends Neurosci. 36, 513-521. doi: 10.1016/j.tins.2013. 06.001

Silverman, A. J., Sutherland, A. K., Wilhelm, M., and Silver, R. (2000). Mast cells migrate from blood to brain. J. Neurosci. 20, 401-408. doi: 10.1523/jneurosci. 20-01-00401.2000

Skaper, S. D., Facci, L., Kee, W. J., and Strijbos, P. J. (2001). Potentiation by histamine of synaptically mediated excitotoxicity in cultured hippocampal neurones: a possible role for mast cells. J. Neurochem. 76, 47-55. doi: 10.1046/ j.1471-4159.2001.00008.x

Skaper, S. D., Giusti, P., and Facci, L. (2012). Microglia and mast cells: two tracks on the road to neuroinflammation. FASEB J. 26, 3103-3117. doi: 10.1096/fj.11197194

Smolders, S., Smolders, S. M., Swinnen, N., Gartner, A., Rigo, J. M., Legendre, P., et al. (2015). Maternal immune activation evoked by polyinosinic:polycytidylic acid does not evoke microglial cell activation in the embryo. Front. Cell Neurosci. 9:301. doi: 10.3389/fncel.2015.00301

Smolders, S. M., Kessels, S., Vangansewinkel, T., Rigo, J. M., Legendre, P., and Brone, B. (2019). Microglia: Brain cells on the move. Prog Neurobiol 178:101612. doi: 10.1016/j.pneurobio.2019.04.001

Sochocka, M., Diniz, B. S., and Leszek, J. (2017). Inflammatory response in the CNS: Friend or Foe? Mol. Neurobiol. 54, 8071-8089. doi: 10.1007/s12035-0160297-1

Song, Y., Lu, M., Yuan, H., Chen, T., and Han, X. (2020). Mast cell-mediated neuroinflammation may have a role in attention deficit hyperactivity disorder (Review). Exper. Therapeutic Med. 20, 714-726. doi: 10.3892/etm.2020. 8789

Souders, M. C., Zavodny, S., Eriksen, W., Sinko, R., Connell, J., Kerns, C., et al. (2017). Sleep in children with autism spectrum disorder. Curr. Psychiatry Rep. 19:34.

Southam, E., Cilia, J., Gartlon, J. E., Woolley, M. L., Lacroix, L. P., Jennings, C. A., et al. (2009). Preclinical investigations into the antipsychotic potential of the novel histamine H3 receptor antagonist GSK207040. Psychopharmacology 201, 483-494. doi: 10.1007/s00213-008-1310-9

Stenesen, D., Moehlman, A. T., and Kramer, H. (2015). The carcinine transporter CarT is required in Drosophila photoreceptor neurons to sustain histamine recycling. Elife 4:e10972.

Stevens, B., Allen, N. J., Vazquez, L. E., Howell, G. R., Christopherson, K. S., Nouri, N., et al. (2007). The classical complement cascade mediates CNS synapse elimination. Cell 131, 1164-1178. doi: 10.1016/j.cell.2007. 10.036

Stevenson, J., Sonuga-Barke, E., Mccann, D., Grimshaw, K., Parker, K. M., Rose-Zerilli, M. J., et al. (2010). The role of histamine degradation gene polymorphisms in moderating the effects of food additives on children's ADHD symptoms. Am. J. Psychiatry 167, 1108-1115. doi: 10.1176/appi.ajp.2010. 09101529

Strakhova, M. I., Nikkel, A. L., Manelli, A. M., Hsieh, G. C., Esbenshade, T. A., Brioni, J. D., et al. (2009). Localization of histamine H4 receptors in the central nervous system of human and rat. Brain Res. 1250, 41-48. doi: 10.1016/j. brainres.2008.11.018

Suzuki, K., Sugihara, G., Ouchi, Y., Nakamura, K., Futatsubashi, M., Takebayashi, K., et al. (2013). Microglial activation in young adults with autism spectrum disorder. JAMA Psychiatry 70, 49-58.

Swinnen, N., Smolders, S., Avila, A., Notelaers, K., Paesen, R., Ameloot, M., et al. (2013). Complex invasion pattern of the cerebral cortex bymicroglial cells during development of the mouse embryo. Glia 61, 150-163. doi: 10.1002/glia. 22421

Szakacs, Z., Dauvilliers, Y., Mikhaylov, V., Poverennova, I., Krylov, S., Jankovic, S., et al. (2017). Safety and efficacy of pitolisant on cataplexy in patients with narcolepsy: a randomised, double-blind, placebo-controlled trial. Lancet Neurol. 16, 200-207.

Takahashi, K., Lin, J. S., and Sakai, K. (2006). Neuronal activity of histaminergic tuberomammillary neurons during wake-sleep states in the mouse. J. Neurosci. 26, 10292-10298. doi: 10.1523/jneurosci.2341-06.2006

Takahashi, K., Liu, F. C., Hirokawa, K., and Takahashi, H. (2003). Expression of Foxp2, a gene involved in speech and language, in the developing and adult striatum. J. Neurosci. Res. 73, 61-72. doi: 10.1002/jnr.10638

Tepper, J. M., Sharpe, N. A., Koos, T. Z., and Trent, F. (1998). Postnatal development of the rat neostriatum: electrophysiological, light- and electronmicroscopic studies. Dev. Neurosci. 20, 125-145. doi: 10.1159/000017308

Tetreault, N. A., Hakeem, A. Y., Jiang, S., Williams, B. A., Allman, E., Wold, B. J., et al. (2012). Microglia in the cerebral cortex in autism. J. Autism Dev. Disord. 42, 2569-2584. doi: 10.1007/s10803-012-1513-0

Thangam, E. B., Jemima, E. A., Singh, H., Baig, M. S., Khan, M., Mathias, C. B., et al. (2018). The role of histamine and histamine receptors in mast cellmediated allergy and inflammation: The hunt for new therapeutic targets. Front. Immunol. 9:1873. doi: 10.3389/fimmu.2018.01873

Theoharides, T. C. (2017). Neuroendocrinology of mast cells: Challenges and controversies. Exp. Dermatol. 26, 751-759. doi: 10.1111/exd.13288

Theoharides, T. C., Angelidou, A., Alysandratos, K. D., Zhang, B., Asadi, S., Francis, K., et al. (2012). Mast cell activation and autism. Biochim. Biophys. Acta 1822, 34-41.

Theoharides, T. C., Asadi, S., Panagiotidou, S., and Weng, Z. (2013). The "missing link" in autoimmunity and autism: extracellular mitochondrial components secreted from activated live mast cells. Autoimmun. Rev. 12, 1136-1142. doi: 10.1016/j.autrev.2013.06.018

Thion, M. S., and Garel, S. (2020). Microglial ontogeny, diversity and neurodevelopmental functions. Curr. Opin. Genet. Dev. 65, 186-194. doi: 10. 1016/j.gde.2020.06.013

Thomsen, G. M., Alkaslasi, M., Vit, J. P., Lawless, G., Godoy, M., Gowing, G., et al. (2017). Systemic injection of AAV9-GDNF provides modest functional improvements in the SOD1G93A ALS rat but has adverse side effects. Gene Ther. 24, 245-252. doi: 10.1038/gt.2017.9

Torrealba, F., Riveros, M. E., Contreras, M., and Valdes, J. L. (2012). Histamine and motivation. Front. Syst. Neurosci. 6:51. doi: 10.3389/fnsys.2012.00051

Torrent, A., Moreno-Delgado, D., Gomez-Ramirez, J., Rodriguez-Agudo, D., Rodriguez-Caso, C., Sanchez-Jimenez, F., et al. (2005). H3 autoreceptors modulate histamine synthesis through calcium/calmodulin- and cAMPdependent protein kinase pathways. Mol. Pharmacol. 67, 195-203. doi: 10.1124/ mol.104.005652

Tremblay, M., Lowery, R. L., and Majewska, A. K. (2010). Microglial interactions with synapses are modulated by visual experience. PLoS Biol. 8:e1000527. doi: 10.1371/journal.pbio.1000527

Trotti, L. M. (2020). Treat the symptom, not the cause? pitolisant for sleepiness in obstructive Sleep Apnea. Am. J. Respir. Crit. Care Med. 201, 1033-1035. doi: 10.1164/rccm.202001-0104ed

Tsilioni, I., Dodman, N., Petra, A. I., Taliou, A., Francis, K., Moon-Fanelli, A., et al. (2014). Elevated serum neurotensin and CRH levels in children with autistic spectrum disorders and tail-chasing Bull Terriers with a phenotype similar to autism. Transl. Psychiatry 4:e466. doi: 10.1038/tp.2014.106

Vanhala, A., Yamatodani, A., and Panula, P. (1994). Distribution of histamine-, 5hydroxytryptamine-, and tyrosine hydroxylase-immunoreactive neurons and 
nerve fibers in developing rat brain. J. Comp. Neurol. 347, 101-114. doi: 10 . 1002/cne.903470108

Vargas, D. L., Nascimbene, C., Krishnan, C., Zimmerman, A. W., and Pardo, C. A. (2005). Neuroglial activation and neuroinflammation in the brain of patients with autism. Ann. Neurol. 57, 67-81. doi: 10.1002/ana.20315

Verhoeven, W. M. A., Egger, J. I. M., Janssen, P. K. C., and Van Haeringen, A. (2020). Adult male patient with severe intellectual disability caused by a homozygous mutation in the HNMT gene. BMJ Case Rep. 13:e235972. doi: 10.1136/bcr-2020-235972

Volterra, A., and Meldolesi, J. (2005). Astrocytes, from brain glue to communication elements: the revolution continues. Nat. Rev. Neurosci. 6, 626-640. doi: $10.1038 / \mathrm{nrn} 1722$

Wada, H., Inagaki, N., Itowi, N., and Yamatodani, A. (1991). Histaminergic neuron system: morphological features and possible functions. Agents Actions Suppl. 33, 11-27. doi: 10.1007/978-3-0348-7309-3_1

Wahis, J., Hennes, M., Arckens, L., and Holt, M. G. (2021). Star power: the emerging role of astrocytes as neuronal partners during cortical plasticity. Curr. Opin. Neurobiol. 67, 174-182. doi: 10.1016/j.conb.2020.12.001

Weisler, R. H., Pandina, G. J., Daly, E. J., Cooper, K., and Gassmann-Mayer, C. (2012). Randomized clinical study of a histamine H3 receptor antagonist for the treatment of adults with attention-deficit hyperactivity disorder. CNS Drugs 26, 421-434. doi: 10.2165/11631990-000000000-00000

Wilens, T. E. (2006). Mechanism of action of agents used in attentiondeficit/hyperactivity disorder. J. Clin. Psychiatry 67, 32-38.

Wilhelm, M., Silver, R., and Silverman, A. J. (2005). Central nervous system neurons acquire mast cell products via transgranulation. Eur. J. Neurosci. 22, 2238-2248. doi: 10.1111/j.1460-9568.2005.04429.x

Wright, C., Shin, J. H., Rajpurohit, A., Deep-Soboslay, A., Collado-Torres, L., Brandon, N. J., et al. (2017). Altered expression of histamine signaling genes in autism spectrum disorder. Transl. Psychiatry 7:e1126. doi: 10.1038/tp.2017.87

Wu, Y., Dissing-Olesen, L., Macvicar, B. A., and Stevens, B. (2015). Microglia: dynamic mediators of synapse development and plasticity. Trends Immunol. 36, 605-613. doi: 10.1016/j.it.2015.08.008

Xia, P., Logiacco, F., Huang, Y., Kettenmann, H., and Semtner, M. (2021). Histamine triggers microglial responses indirectly via astrocytes and purinergic signaling. Glia doi: 10.1002/glia.24039 [Epub ahead of print].

Xing, Z., Gauldie, J., Cox, G., Baumann, H., Jordana, M., Lei, X. F., et al. (1998). IL-6 is an antiinflammatory cytokine required for controlling local or systemic acute inflammatory responses. J. Clin. Invest. 101, 311-320. doi: 10.1172/jci1368

Xu, J., Zhang, X., Qian, Q., Wang, Y., Dong, H., Li, N., et al. (2018). Histamine upregulates the expression of histamine receptors and increases the neuroprotective effect of astrocytes. J Neuroinflamm. 15:41.

Xu, Y., An, F., Borycz, J. A., Borycz, J., Meinertzhagen, I. A., and Wang, T. (2015). Histamine recycling is mediated by CarT, a carcinine transporter in drosophila photoreceptors. PLoS Genet. 11:e1005764. doi: 10.1371/journal.pgen.1005764

Yamatodani, A., Maeyama, K., Watanabe, T., Wada, H., and Kitamura, Y. (1982). Tissue distribution of histamine in a mutant mouse deficient in mast cells: clear evidence for the presence of non-mast-cell histamine. Biochem. Pharmacol. 31, 305-309. doi: 10.1016/0006-2952(82)90175-7

Yamazaki, M., Tsujimura, T., Morii, E., Isozaki, K., Onoue, H., Nomura, S., et al. (1994). C-kit gene is expressed by skin mast cells in embryos but not in puppies of Wsh/Wsh mice: age-dependent abolishment of c-kit gene expression. Blood 83, 3509-3516. doi: 10.1182/blood.v83.12.3509.3509

Yanni, D., Korzeniewski, S. J., Allred, E. N., Fichorova, R. N., O’shea, T. M., Kuban, K., et al. (2017). Both antenatal and postnatal inflammation contribute information about the risk of brain damage in extremely preterm newborns. Pediatr. Res. 82, 691-696. doi: 10.1038/pr.2017.128

Yoo, H. (2015). Genetics of autism spectrum disorder: current status and possible clinical applications. Exp. Neurobiol. 24, 257-272. doi: 10.5607/en.2015.24.4. 257

Yoshikawa, T., Naganuma, F., Iida, T., Nakamura, T., Harada, R., Mohsen, A. S., et al. (2013). Molecular mechanism of histamine clearance by primary human astrocytes. Glia 61, 905-916. doi: 10.1002/glia.22484

Yoshikawa, T., Nakamura, T., and Yanai, K. (2021). Histaminergic neurons in the tuberomammillary nucleus as a control centre for wakefulness. Br. J. Pharmacol. 178, 750-769. doi: 10.1111/bph.15220

Zecharia, A. Y., Yu, X., Gotz, T., Ye, Z., Carr, D. R., Wulff, P., et al. (2012). GABAergic inhibition of histaminergic neurons regulates active waking but not the sleep-wake switch or propofol-induced loss of consciousness. J. Neurosci. 32, 13062-13075. doi: 10.1523/jneurosci.2931-12.2012

Zhan, Y., Paolicelli, R. C., Sforazzini, F., Weinhard, L., Bolasco, G., Pagani, F., et al. (2014). Deficient neuron-microglia signaling results in impaired functional brain connectivity and social behavior. Nat. Neurosci. 17, 400-406. doi: 10. 1038/nn.3641

Zhang, J., Tan, H., Jiang, W., and Zuo, Z. (2014). Amantadine alleviates postoperative cognitive dysfunction possibly by increasing glial cell line-derived neurotrophic factor in rats. Anesthesiology 121, 773-785. doi: 10.1097/aln. 0000000000000352

Zhang, J.-M., Wang, H.-K., Ye, C.-Q., Ge, W., Chen, Y., Jiang, Z.-L., et al. (2003). ATP released by astrocytes mediates glutamatergic activity-dependent heterosynaptic suppression. Neuron 40, 971-982. doi: 10.1016/s0896-6273(03) 00717-7

Zhang, S., Edwards, T. N., Chaudhri, V. K., Wu, J., Cohen, J. A., Hirai, T., et al. (2021). Nonpeptidergic neurons suppress mast cells via glutamate to maintain skin homeostasis. Cell 184:e2116.

Zhang, W., Zhang, X., Zhang, Y., Qu, C., Zhou, X., and Zhang, S. (2020). Histamine induces microglia activation and the release of proinflammatory mediators in rat brain via H(1)R or H(4)R. J. Neuroimmun. Pharmacol. 15, 280-291. doi: 10.1007/s11481-019-09887-6

Zhu, J., Qu, C., Lu, X., and Zhang, S. (2014). Activation of microglia by histamine and substance P. Cell Physiol. Biochem. 34, 768-780. doi: 10.1159/000363041

Conflict of Interest: The authors declare that the research was conducted in the absence of any commercial or financial relationships that could be construed as a potential conflict of interest.

Copyright (c) 2021 Carthy and Ellender. This is an open-access article distributed under the terms of the Creative Commons Attribution License (CC BY). The use, distribution or reproduction in other forums is permitted, provided the original author(s) and the copyright owner(s) are credited and that the original publication in this journal is cited, in accordance with accepted academic practice. No use, distribution or reproduction is permitted which does not comply with these terms. 